\title{
POSKUS REKONSTRUKCIJE REPERTOARJA LATINSKIH CERKVENIH SKLADB NA KORU LJUBLJANSKE STOLNICE V ČASU DELOVANJA ANTONA FOERSTERJA (1868-1908)
}

\author{
ALEŠ NAGODE \\ Filozofska fakulteta Univerze v Ljubljani
}

Izvleček: Prispevek poskuša na podlagi skromnih ohranjenih virov rekonstruirati repertoar latinskih cerkvenih skladb na koru ljubljanske stolnice, ki je pomemben za razumevanje razvojnih tokov $v$ slovenski cerkveni glasbi druge polovice 19. stoletja. Zbrani podatki kažejo, da pomeni Foersterjevo delovanje globok prelom s tradicijo in dosledno uveljavitev cecilijanskih načel.

Ključne besede: Anton Foerster, cecilijanstvo, repertoar
Abstract: The author attempts to reconstruct the repertoire of the Ljubljana cathedral choir, which is very important for understanding the developments in $19^{\text {th }}$ century Slovenian church music. The gathered data show that Foerster's era was characterised by a deep breach of tradition and painstaking application of Cecilian principles.

Keywords: Anton Foerster, Caecilian movement, repertoire

Natančnejši vpogled v repertoar glasbenega kora ljubljanske stolnice pod vodstvom Antona Foersterja je za glasbenega zgodovinarja zanimiv iz več razlogov. V drugi polovici 19. stoletja so katoliško cerkveno glasbo zajele globoke in večplastne spremembe. Na eni strani se je znašla na obrobju zanimanja laiziranega sveta, ki je več pozornosti namenjal privlačnejšim ali politično bolj aktualnim glasbenim zvrstem. Po drugi strani pa je tudi navznoter doživljala soočanje različnih pogledov na pomen in vlogo cerkvene glasbe, značilnih za čas, ko se izčrpajo uveljavljeni estetski in organizacijski koncepti. Iskanje novih rešitev se je izražalo v največkrat konfliktnem sobivanju tako nasprotujočih si teženj kot so bile nostalgično ohranjanje reprezentativne cerkvene glasbe iz druge polovice 18. stoletja in iskanje "prave« cerkvene glasbe $\mathrm{z}$ romantičnim obnavljanjem srednjeveškega korala ter posnemanjem vokalne polifonije 16. stoletja, ali ustvarjanje sodobne, skrajno individualistično izpovedne cerkvene glasbe ob utilitarističnem postrazsvetljenskem zavračanju estetsko zahtevne cerkvene glasbe in propagiranju ljudskega petja.

Ljubljanska stolnica je skoraj idealna »točka opazovanja« teh sprememb v slovenskem prostoru, še zlasti če želimo vzpostaviti primerjavo s sočasnim razvojem v drugih katoliških deželah srednje Evrope. Njen kor je imel namreč za slovenski prostor izjemen formalen in simbolen pomen. Pomembno težo je njegovemu delovanju dajal formalni položaj cerkve v kateri je deloval. Brez dvoma je bila glasbena podoba bogoslužja v osrednji cerkvi škofije zgled in spodbuda manjšim mestnim in podeželskim cerkvam pri oblikovanju cerkvene glasbe. Hkrati pa je bil stolni kor tudi ustanova, ki se je ponašala z - za slovenske razmere 
zelo redkim - slovesom večstoletnega neprekinjenega delovanja. V skoraj vsem tem času je po ambicijah in materialnih možnostih, večinoma pa tudi po poustvarjalnih dosežkih presegala vse druge podobne glasbene ustanove na Slovenskem.

Radij vpliva stolnega kora pa se ni ustavljal na mejah ljubljanske škofije. Ta se je v veliko manjši meri kot druge slovenske škofije srečevala $\mathrm{z}$ narodno obrambno problematiko in vsaj v cerkveni sferi navznoter doživljala razvoj primerljiv tistemu v drugih evropskih deželah. Kot škofijsko središče neformalne nacionalne - ali vsaj kulturne - prestolnice, je ljubljanska škofija - vsaj v zadevah cerkvene glasbe kot pretežno kulturnem vprašanju - vse močneje vplivala tudi na slovenska območja lavantinsko-mariborske in tržaško-koprske škofije ter goriške nadškofije. Ta vpliv je bil še močnejši spričo umeščenosti drugih slovenskih škofijskih središč (Maribor, Gorica, Trst) v narodnostno mešano, oz. ponekod celo večinsko tujejezično okolje. Posebej očitno se je to pokazalo z ustanovitvijo Cecilijinega društva za ljubljansko škofijo, ki je kljub formalnemu obstoju sorodnih društev v lavantinsko-mariborski in goriški diecezi s svojim delovanjem in članstvom dejansko zajelo celotno slovensko etnično ozemlje.

Pomembno pa k zanimivosti delovanja stolnega kora prispeva tudi njegov vodja - Anton Foerster. Z njim je umetniško vodenje te ustanove po dolgem času prevzela osebnost, ki se je ponašala $\mathrm{z}$ za slovenske razmere nadpovprečno glasbeno razgledanostjo in izobrazbo, hkrati pa se je zaradi globoke vernosti in pobožnosti zavedala tudi tiste dimenzije cerkvene glasbe, ki presega strokovno neoporečno opravljanje ustvarjalskih in poustvarjalskih nalog. $\mathrm{Z}$ njegovim prihodom se je - kljub materialno neugodnim razmeram, o katerih bomo spregovorili nekoliko kasneje - pravzaprav šele odprla možnost za vključitev delovanja stolnega kora $\mathrm{v}$ evropske cerkvenoglasbene tokove.

Delovanje stolnega kora v obravnavanem času do sedaj še ni bilo deležno bolj poglobljene znanstvene obravnave. Avtorji, ki so opazovali življenje in delo Antona Foersterja, so se večinoma le površno dotaknili tega, pravzaprav osrednjega dela njegovega glasbeniškega delovanja in so večino pozornosti - skladno z duhom časa - namenjali njegovemu ustvarjalnemu in poustvarjalnemu delu v posvetni glasbi. ${ }^{1}$ Zato naše poznavanje delovanja stolnega kora v drugi polovici 19. stoletja močno zaostaja za vedenjem o delovanju te ustanove v prejšnjih stoletjih, ki je večinoma plod izčrpnih raziskav Janeza Höflerja. ${ }^{2}$

Nekoliko so k takemu stanju prispevali tudi skromni viri, ki so na razpolago za oblikovanje vpogleda v izvajani repertoar. Žal Foerster sam ni v celoti sledil praktičnim smernicam, ki jih je cecilijanska literatura priporočala organistom, namreč, naj skrbno inventarizirajo cerkveni arhiv, vodijo seznam izvajanih skladb in redno poročajo v strokovna glasila. Tako nimamo natančnega dnevnika izvajanega repertoarja, kakršnega je npr. vodil njegov naslednik Stanko Premrl, niti inventarja stolnega glasbenega arhiva v obravnavanem času. Foerster je le občasno poročal o izvajanem repertoarju v domačem in tujem tisku, pa še to le s površnimi navedbami.

Zares izčrpno je bilo le njegovo prvo poročilo, ki ga je leta 1876 sestavil za osrednje

\footnotetext{
Članki v Foersterjev zbornik, ur. Edo Škulj, Ljubljana, Družina, 1998.

2 Janez Höfler, Tokovi glasbene kulture na Slovenskem od začetkov do 19. stoletja, Ljubljana, Mladinska knjiga, 1970; Janez Höfler, Glasbena umetnost pozne renesanse in baroka na Slovenskem, Ljubljana, Partizanska knjiga, 1978; Janez Höfler, Glasbena kapela ljubljanske stolnice 1800-1810, Muzikološki zbornik 17/1 (1981), str. 7-21.
} 
nemško cecilijansko glasilo Musica sacra. ${ }^{3}$ Sestavek obsega popoln seznam z navedbami avtorjev in naslovov izvajanih skladb, ki je razčlenjen po različnih vrstah skladb (1. instrumentalne maše, 2. vokalne maše ali maše z orgelsko spremljavo, 3. maše za rajne, 4. moteti, 5. marijanske skladbe, 6. Te Deumi in 7. Tantum ergo).

Bistveno manj povedna so njegova poročila, ki jih je v naslednjih letih pošiljal reviji Cerkveni glasbenik. Razdelimo jih lahko v dve skupine. V letih 1882 (januar), 1886, 1891 in $1901^{4}$ je poročal o celotnem repertoarju stolnega kora. Ta poročila so zelo površna in so očitno imela samo ta namen, da pokažejo doslednost izvajanja cecilijanskih načel in za slovenske razmere velik obseg repertoarja, ki ga je bil sposoben izvesti Foersterjev zbor. Bistvena pomanjkljivost je za današnjega opazovalca zlasti v tem, da v njih navaja le skupno število skladb v posamezni skupini in seznam imen izvajanih avtorjev, ne pa tudi naslovov izvajanih skladb. Iz primerjave poročil je jasno razvidno, da je Foerster v teku let, ki jih je preživel v stolniški službi, namenjal točni evidenci izvajanega repertoarja vedno manj pozornosti. Njegove navedbe so vedno bolj nezanesljive, saj se v kasnejših poročilih zadovoljuje $\mathrm{z}$ vedno bolj površnimi ocenami števila izvajanih skladb (npr. »jako veliko«, »ok.«, »več kot«ipd.), pa tudi seznam skladateljev je vedno manj natančen. Če navaja leta 1882 skoraj vse izvajane avtorje - kar se da ugotoviti iz poskusa rekonstrukcije - se leta 1891 omeji le na številčne podatke in navajanje t. i. "starejših « avtorjev (16. in 17. stol.). Leta 1901 se popolnoma odpove navajanju avtorjev manjših cerkvenih skladb (motetov), ki seveda predstavljajo najštevilnejšo skupino.

Drugo skupino poročil predstavljajo dopisi iz let 1880, 1882 (maj), 1883 in 1887, ${ }^{5} \mathrm{ki}$ prinašajo pregled izvajanih skladb v velikonočnem tednu $(1880,1882,1883)$ oz. božičnih praznikih (1887). Ta poročila so doslednejša, saj navajajo celovit pregled glasbe izvajanje pri določeni bogoslužni slovesnosti, z navedbami avtorjev skladb in naslova oz. funkcije, ki so jo v obredju imele (gradual, ofertorij, ipd.).

Iz omenjenih poročil lahko izluščimo okvirne podatke o izvajanem repertoarju, ki so zbrani v tabelah 1 in 2 . Tabela 1 (gl. str. 101) prinaša pregled skupnega števila izvajanih skladb v posamezni skupini. Podatki za leta 1882, 1886, 1891 in 1901 so povzeti po Foersterjevih navedbah, primerjalni številčni podatki za leto 1876 pa so pridobljeni s štetjem, na podlagi objavljenega seznama izvedenih skladb. V tabeli 2 (gl. str. 103) so zbrani avtorji in naslovi skladb, ki jih je bilo možno z večjo ali manjšo zanesljivostjo identificirati. Podobno kot v virih so razdeljeni v več skupin (Maše, Requiemi, Moteti, Tantum ergo, Te Deum). Delitev $\mathrm{v}$ skupine je v primerjavi z viri nekoliko poenostavljena, saj je to omogočilo lažjo ureditev in primerjavo podatkov za posamezna leta. Imena avtorjev in naslovi skladb so navedeni $\mathrm{z} \mathrm{v}$ virih prevladujočo obliko, vsi avtorjevi dodatki so v oglatem oklepaju. Podatki za leto 1876 so prevzeti iz Foersterjevega seznama, ki navaja avtorje in naslove izvajanih skladb. Prav

3 Anton Förster, Aufführungen des Domchores zu Laibach in Krain (Österreich) seit Juli 1868 bis August 1876, Musica sacra 9 (1876), str. 101-102.

${ }^{4}$ Iz Ljubljane, Cerkveni glasbenik 5 (1882), str. 5-6. Iz Ljubljane, Cerkveni glasbenik 9 (1886), str. 56; Ljubljana, Cerkveni glasbenik 14 (1891), str. 79; Iz Ljubljane, Cerkveni glasbenik 24 (1901), str. 38 .

5 V Ljubljani, Cerkveni glasbenik 3 (1880), str. 30; Iz Ljubljane, Cerkveni glasbenik 5 (1882), str. 37-38; Iz Ljubljane, Cerkveni glasbenik 6 (1883), str. 28-29; Iz Ljubljane, Cerkveni glasbenik 10 (1887), str. 4-5. 
tako so popolnoma zanesljivi podatki o skladbah, izvedenih v velikonočnih oz. božičnih praznikih v letih 1880, 1882, 1883 in 1887. Ostali v tabeli navedeni podatki (torej o izvajanju posameznih skladb v letih 1882, 1886, 1891 in 1901) temeljijo na avtorjevih domnevah, zato so v tabeli postavljeni v oglati oklepaj. Te domneve temeljijo zlasti na opazovanju znanih podatkov, ki kažejo, da je bil izbor izvajanih skladb sorazmerno stalen. Pomembna pomoč pri identifikaciji nekaterih skladb in povečanju zanesljivosti omenjenih domnev je bil tudi rokopisni inventarni popis notnega arhiva stolnega kora, ki sta ga je leta 1944 sestavila Venceslav Snoj in p. Alojzij Mav. ${ }^{6}$ Lahko namreč domnevamo, da izbor v njem navedenih starejših cecilijanskih skladb v grobih obrisih predstavlja stanje ob Foersterjevem odhodu, saj se fond tovrstnih skladb pod njegovimi nasledniki ni več bistveno povečeval (oz. celo nasprotno, bil je izločen kot neuporaben za vsakodnevo rabo).

Podatki o izvajanih skladbah so dopolnjeni z navedbo števila neidentificiranih skladb v posamezni skupini. Ta števila so gotovo okvirni pokazatelj zanesljivosti rekonstruiranega izbora skladb. Medtem ko se delež neugotovljenih del pri večini skupin giblje od 0 do $30 \%$, je občutno večji zlasti pri motetih. To moramo pripisati zlasti dejstvu, da je Foerster številne manjše skladbe - zlasti mašne proprije - črpal iz večjih zbirk tovrstnih skladb (svoje lastne Gradualia, tractus et sequentiae, op. 54, Ljubljana 1893 (samozaložba) ali Lauda Sion, ur. Emil Nickl) in da njihovih naslovov in avtorstva ni dosledno navajal. ${ }^{7}$ Nekatera od neprepoznanih del lahko iščemo med skladbami avtorjev, ki so v poročilih zastopani z neidentificiranimi skladbami (navedeni so na koncu tabele 2), ali med deli starocecilijanskih avtorjev vsebovanih v že omenjenem popisu stolnega arhiva iz leta 1944. Vsekakor nepopolnost in hipotetičnost rekonstruiranega seznama del zmanjšuje možnost podrobnega opazovanja izvajanega repertoarja (npr. katera dela posameznega skladatelja so bila v katerem letu izvedena, ipd.), kljub temu pa dajejo tako urejeni podatki dovolj podlage za oblikovanje vedenja o temeljnih potezah izvajanega repertoarja.

Leta 1868, ko je Foerster nastopil službo regensa chori stolne cerkve, so v slovenskem časopisju že celih dvajset let tekle razprave o nujno potrebni reformi cerkvene glasbe. Tudi nekatere ideje, ki so kasneje postale jedro cecilijanskega programa, niso bile nikakršna novost. Dejansko so vsi vodilni v Ljubljani delujoči glasbeniki tako ali drugače delali prve korake v tej smeri. Kamilo Mašek je v reviji Cäcilia objavljal navodila za organiste, ki naj bi pomagali pri liturgično pravilnem izvajanju petja, hkrati pa opozarjal na skladatelje 16. in 17. stoletja, postavljal njihove skladbe za zgled primerne cerkvene glasbe in s tem utrjeval nove historistične poglede. ${ }^{8}$ Stolni kor je že v času Gregorja Riharja nakupoval temeljne nemške cecilijanske izdaje in ob posebnih priložnostih izvajal dela vokalne polifonije 16. stoletja. ${ }^{9}$ Tudi Anton Nedved je večkrat opozoril na neurejenost cerkveno-glasbenih razmer. ${ }^{10}$

6 Hrani ga arhiv kora ljubljanske stolnice.

7 Iz Ljubljane, Cerkveni glasbenik 24 (1901), str. 38.

8 Biografische Skizzen berühmter Kirchen-Tondichter, Cäcilia 1 (1857/58), str. 34, 52, 121, 2 (1859), str. 7, 29-30.

9 Viktor Steska, Glasbeni inventar stolnega kora v Ljubljani pod Gregorjem Riharjem, Cerkveni glasbenik 51 (1928), str. 113-119; Aleš Nagode, Starejše slovensko cecilijanstvo in Gregor Rihar, Muzikološki zbornik 34 (1998), str. 89-99.

${ }^{10}$ Nedved naj bi pri pouku učiteljskih pripravnikov glede prevlade Riharjevih skladb izjavil: »Diesem Elende in Krain muß ein Ende gemacht werden!« in »... möglich, daß Rihar Verdienste um den 
Zato ne preseneča, da so se dejavna prizadevanja za reformo cerkvene glasbe $\mathrm{v}$ ljubljanski stolnici začela takoj po Foersterjevem prihodu. Stolni prošt Janez Z. Pogačar je že naslednje leto izdal javno okrožnico, ${ }^{11} \mathrm{ki}$ je predstavila načrt za izboljšanje cerkvene glasbe v ljubljanski stolnici. Skladno s cecilijanskimi načeli je posebno pozornost namenil glasbi pri petih (latinskih) mašah, pri katerih naj bi se $\mathrm{v}$ bodoče strogo upoštevali vsi cerkveni predpisi in odstranile vse $\mathrm{v}$ desetletjih uveljavljene »razvade «. V glasbenem pogledu se avtor - sklicujoč se na avtoriteto vodilnih cecilijancev Franza Witta, Carla Proskeja in Ignaza Oberhoferja - zavzema za odstranitev klasicističnega in zgodnjeromantičnega vokalnoinstrumetnalnega cerkvenega repertoarja. Ta je po njegovem mnenju neprimeren, saj naj bi nastajal v času največjega propada cerkvene glasbe, čigar vplivu se niso mogli izogniti niti velikani, kot so bili Haydn, Mozart in Beethoven. Nadomestila naj bi ga cecilijanskim idealom ustrezna dela, predvsem gregorijanski koral, vokalna polifonija 16. in 17. stoletja ter v duhu obeh komponirana, torej predvsem cecilijanska sodobna cerkvena glasba. Za izvajanje novega repertoarja je okrožnica predvidevala povečanje pevskega zbora, ki bi s tem postal ansambel, ustrezen zvočnemu idealu 19. stoletja. Zgornje glasove naj bi - po končanem pevskem šolanju - izvajali deški pevci, ki bi za svoje sodelovanje prejemali tudi honorar.

Drugi del, ki se posveča predvsem materialni plati načrtovane reforme, pa razkriva še drugo plat okrožnice. Njena objava je bila namreč predvsem poskus, da bi po zgledih iz tujine za vzdrževanje cerkvene glasbe v stolnici pridobili materialno podporo javnosti. Cerkev sama oz. stolni kapitelj, ki je bil zadolžen za vzdrževanje stolnice in bogoslužja v njej, ni več razpolagal s sredstvi, ki so še v 18. stoletju omogočala vzdrževanje znatnega vokalnoinstrumentalnega ansambla. Ta sredstva, izgubljena predvsem v času jožefinskih reform in francoske okupacije, so želeli nadomestiti z ustanovitvijo društva, katerega prispevki bi vzdrževali pomembnosti cerkve primerno izvajalsko telo.

Finančni del načrta ni imel uspeha, saj cilji cecilijanske reforme očitno niso navdušili ljubljanskega občinstva. To pa ni ustavilo Foersterjevih prizadevanj za izvedbo reforme. Uspelo mu je celo sestaviti deški zbor, ki je sprva štel 50 pevcev, vendar je ta kmalu zamrl. ${ }^{12}$ Foerster se je zato odločil za drugačno pot. Zbral je številčno precej skromnejši ljubiteljski pevski zbor, ki je nato v nespremenjenem obsegu (20-30 članov) deloval vse do njegove upokojitve leta $1908 .{ }^{13} \mathrm{Z}$ njim je v nekaj naslednjih letih do te mere preobrazil repertoar, da se je lahko leta 1876 z dopisom, v katerem je popisal svoje dosežke, predstavil evropski cecilijanski javnosti.

Če poskušamo primerjati Foersterjev repertoar iz leta 1876 z repertoarjem njegovih predhodnikov, naletimo zopet na omejitve, ki jih predstavljajo izredno skopi viri. Edina možnost za vpogled v izvajani repertoar pred Feoersterjevim prihodom (1868) je zato inventarni popis stolnih muzikalij, ki je bil izdelan leta 1865, torej po smrti Gregorja Riharja

Kirchenmusik hatte!«. Njegov poskus, da bi leta 1865 nadomestil petje Riharjevih štiriglasnih antifon pri večernicah z enoglasnimi, verjetno koralnimi, je naletel na ostre reakcije v celovškem Slovencu in Novicah, ki so ta poseg imenovale »kolosalna predrznost«. Slovenec 1 (1865), str. 99. Novice 23 (1865), str. 123.

${ }^{11}$ Triglav 4 (1869), str. 4-6.

${ }^{12}$ Andrej Karlin, Spominska knjižica, Ljubljana, Cecilijino društvo, 1902, str. 6.

${ }^{13}$ Ljubljana, Cerkveni glasbenik 14 (1891), str. 79. 
in v času delovanja njegovega nečaka Gregorja Riharja ml. ${ }^{14}$ Če torej Foersterjevo poročilo iz leta $1876^{15}$ primerjamo z omenjenim popisom, lahko ugotovimo, da je novi vodja v repertoar vključil le redke starejše skladbe. Če poskušamo to predstaviti s številkami: iz starejšega časa je bila pri Foersterju le 1 od 33 maš, 1 od 8 maš za rajne, 5 od 218 motetov in nobena skladba iz drugih zvrsti. Če upoštevamo, da je bilo v stolnem arhivu pred Foersterjevim prihodom že 250-300 skladb, lahko ugotovimo, da je bila prenova izvajanega repertoarja temeljita.

Tako globok rez je bil brez dvoma posledica več vzrokov. Verjetno je k temeljitosti reforme prispevalo tudi dejstvo, da je Foerster svoj ansambel izoblikoval skoraj na novo. Repertoar je moral tako oblikovati iz nič, zato se mu ni bilo treba upirati niti skušnjavi, da bi si delo olajšal s prevzemanjem že naučenih skladb. Njegova reformistična naravnanost je tako lahko prišla v polnosti do izraza. Že površen pogled na inventarni popis stolnih muzikalij nam pokaže, da je bila glavnina $v$ njem vsebovanega repertoarja za Foersterja popolnoma nesprejemljiva. Vsebuje namreč predvsem skladbe, ki so daleč v 19. stoletje ohranjale značilnosti klasicistične vokalno-instrumentalne cerkvene glasbe. Z največjim številom skladb zastopani tuji (Anton Diabelli, Joseph Eybler, Joseph Haydn, Johann B. Schiedermayr) in domači avtorji (Leopold F. Schwerdt, František B. Dussik, Joseph Miksch, deloma tudi Gašper Mašek) so predstavljali prav tisti repertoar, ki ga je načrtovana reforma hotela odstraniti. Izmed starejših muzikalij je prevzel le redka samostojna dela. Njihove avtorje lahko po pravilu uvrstimo med predhodnike cerkvenoglasbene reforme, ki so že v prvi polovici 19. stoletja v svojih skladbah vsaj deloma anticipirali cecilijanska načela. Bernhard Hahn se je odkrito zavzemal za uvajanje historističnega repertoarja, Ambros Rieder, ki je preučeval dela Kirnbergerja, Marpurga in Fuxa, in Gašper Mašek pa sta se vsaj v nekaterih svojih skladbah približala novemu stilnemu idealu. Zmernejšo, v sodobnost naravnano cerkveno glasbo 19. stoletja predstavljajo v svojem času zelo priljubljeni češki skladatelj Joseph Blachak, Joseph Ferdinand Kloss in Heinrich Graf von Bombelles. Iz starejšega gradiva je Foerster brez dvoma uporabil tudi Proskejevo zbirko Musica divina, iz katere je črpal številne skladbe avtorjev 16. in 17. stoletja, ki jih je na stolnem koru izvajal v naslednjih letih. Pri tem pa se postavlja vprašanje, v kakšni meri lahko dela te zbirke prištevamo v riharjanski repertoar. Sama nabava zbirke namreč ne pomeni tudi, da so v njej vsebovana dela dejansko tudi izvajali. Dokazov za številnejše izvedbe tovrstnega repertoarja pred 1868 pa zaenkrat ne poznamo.

Pomemben delež med v novi repertoar uvrščenimi skladbami predstavljajo dela skladateljev 16. stol. ali v stile antico komponirane skladbe skladateljev 17. in 18. stoletja. Teh je manj med večjimi glasbenimi oblikami, npr. samo dve maši (D. Cannicciari in H. L. Hassler), več pa med moteti, kjer najdemo dela skladateljev kot so G. P. da Palestrina, T. L. de Victoria, G. Allegri, A. Antonelli, C. Casciolini, B. Cordans, J. Gallus, Janez IV. Portugalski, G. Olivieri, G. O. Pitoni, A. Scarlatti, G. Turini, L. Grossi da Viadana, A. Lotti in G. B. Martini. Foersterjevo poseganje po tovrstnih delih je razumljivo, saj je bila glasba v slogu vokalne polifonije 16. stol. - oz. slogu, za katerega so v 19. stoletju menili, da je slog 16. stoletja - ob gregorijanskem koralu ideal primerne cerkvene glasbe. Kljub temu, da

\footnotetext{
${ }^{14}$ Viktor Steska, Glasbeni inventar stolnega kora v Ljubljani pod Gregorjem Riharjem, Cerkveni glasbenik 51 (1928), str. 113-119.

${ }^{15}$ Anton Förster, Aufführungen des Domchores zu Laibach in Krain (Österreich) seit Juli 1868 bis August 1876, Musica sacra 9 (1876), str. 101-102.
} 
predstavljajo tovrstna dela po številu, še bolj pa po obsegu le drobec celotnega repertoarja, pa pomeni njihovo kontinuirano izvajanje prvi poskus oživljanja historičnih glasbenih del v slovenskem okolju. Ta dejavnost se je še intenzivirala v naslednjih letih, zlasti z izvedbami večjih Gallusovih (Missa Elisabeth Zachariae, 1891) in Palestrinovih (ena od maš, verjetno Missa Papae Marcelli, 1901) del.

Pretežna glavnina del, sprejetih v repertoar do leta 1876, pa je delo skladateljev, ki so bili tako ali drugače povezani z nemškim ali češkim cecilijanskim gibanjem. Pri tem je zastopan cel prerez kompozicijskih rešitev, s katerimi so ti skladatelji iskali srednjo pot med sodobnim glasbenim stavkom in zahtevami cerkvenoglasbene reforme. $Z$ velikim številom avtorjev in del je zastopana smer, ki je poskušala uresničiti ideal prave cerkvene glasbe s posnemanjem historičnih vzorov. Mednje sodijo zlasti Karl Greith, Michael Haller, F. Koenen, Johann Kaspar Ett, Ferdinand Schaller, Johann Schweitzer in predvsem duhovni vodja nemškega cecilijanstva Franz X. Witt (če naštejemo le najpomembnejše). V to skupino lahko vsaj z nekaterimi deli uvrstimo tudi Antona Foersterja samega, ki se je zlasti pri ustvarjanju manjših cerkvenih skladb na latinska besedila rad opiral na historične zglede. Enako močna je skupina skladateljev, ki so sodobni glasbeni stavek prilagodili cecilijanskim merilom - in s tem v veliki večini ustvarjali plehko, nepomembno porabno glasbo. Med temi avtorji so iz nemškega prostora najpomembnejši Bernhard in Johann Georg Mettenleiter ter G. H. Stehle, močno pa je zastopana tudi zgodnjececilijanska ustvarjalnost češkega prostora, $h$ kateri so prispevali Alois Jelen, Johann Krejči, Jan K. Knahl, Leopold Eugen Mechura, Johann B. Müller in Joseph Gregor Zangl.

Tretjo skupino predstavljajo skladatelji, ki so se pri ustvarjanju svojih cerkvenih skladb najbolj približali sodobnemu glasbenemu stavku ter si s tem v nekaterih primerih nakopali tudi nasprotovanje bolj strogih cecilijanskih kritikov. Izmed njih so v repertoarju zastopani predvsem Gottfried Preyer, Moritz Brosig, Johann K. Aiblinger in Franz Liszt. Z nekaj osamljenimi skladbami je zastopanih tudi nekaj skladateljev iz druge polovice 18. stol. (J. Haydn, W. A. Mozart, L. Hoffmann) pa tudi sodobni skladatelji, ki se niso prvenstveno posvečali ustvarjanju cerkvene glasbe (G. Meyerbeer, F. Mendelssohn-Bartholdy). Vsa v repertoar vključena dela teh skladateljev pripadajo tistim nekaj osamljenim skladbam iz njihovega opusa, ki so ustrezale merilom cecilijanskih kritikov. Njihovo siceršnje cerkvenoglasbeno ustvarjanje pa je po večini zadela anatema necerkvenosti.

\section{Tabela 1}

\begin{tabular}{|l|c|c|c|c|c|}
\hline Kategorija & $\mathbf{1 8 7 6}$ & $\mathbf{1 8 8 2}$ & $\mathbf{1 8 8 6}$ & $\mathbf{1 8 9 1}$ & $\mathbf{1 9 0 1}$ \\
\hline Maše & {$[31]$} & {$[42]$} & 53 & 60 & $70+$ \\
- Instrumentalne & {$[15]$} & 18 & & & \\
- Vokalne & {$[16]$} & 24 & & 13 & 15 \\
\hline Requiemi & {$[8]$} & 10 & 11 & 13 & 200 \\
\hline Moteti & {$[137+]$} & 234 & 308 & $\begin{array}{c}\text { »jako } \\
\text { veliko« }\end{array}$ & \\
- ostali & {$[28]$} & & & & 90 \\
\hline Tantum ergo & {$[109+]$} & & & & 13 \\
\hline Te Deum & {$[45]$} & 70 & 67 & & \\
\hline
\end{tabular}


Če poskušamo iz skopih podatkov izluščiti razvoj repertoarja v naslednjih letih, lahko ugotovimo predvsem to, da se je število izvajanih skladb neprestano povečevalo (gl. tabelo 1 ). Vprašanje ostaja, v kolikšni meri lahko iz večjega števila sklepamo na dejansko širitev repertoarja. Iz celote zbranih podatkov dobimo namreč vtis, da je Foerster z navajanjem velikih števil želel pokazati predvsem obseg $\mathrm{v}$ preteklih letih opravljenega dela in manj dejansko število trenutno (npr. v zadnjem letu) izvajanih skladb. Zato števila verjetno vsebujejo vse do datuma poročila izvajane skladbe, torej tudi tiste, ki so bile iz repertoarja iz različnih razlogov izločene. Posebej nepoveden je podatek o izvajanih motetih. Mednje prišteva Foerster vse manjše cerkvene skladbe (skladbe za mašne proprije, antifone, Vidi aquam, Asperges me, itd.), pri čemer ni jasno, ali števila vključujejo tudi koralno izvedene speve.

Izbor izvajanih skladb je ostajal v temeljnih potezah dejansko skozi ves čas Foersterjevega delovanja na stolnem koru enak. Seznami izvajanih skladateljev v različnih poročilih se spreminjajo le malo, pa še takrat ne moremo z gotovostjo določiti, ali gre za spremembe v repertoarju ali za površnost pri navajanju. Podatki o repertoarju, izvajanem v času velikonočnih praznikov, kažejo, da je izbor skladb celo ob tako pomembni in opazni priložnosti ostajal iz leta v leto enak. Taka stabilnost repertoarja je razumljiva. Izvajanje večglasnih uglasbitev liturgičnih spevov, potrebnih pri slovesnih mašah in drugih bogoslužnih priložnostih, za vse nedelje in praznike v cerkvenem letu, je bila sorazmerno velika naloga za izvajalsko telo, ki je delovalo na ljubiteljski osnovi. To je vsekakor omejevalo morebitne Foersterjeve težnje, da bi liturgično vlogo cerkvenega petja nadgrajeval še z umetniškimi ambicijami. Obenem pa je bil že sicer iz cecilijanskih vrst deležen občasnih kritik, da spreminja bogoslužje v koncertne nastope.

Kljub temu lahko vendar opažamo drobne, vendar vsebinsko značilne spremembe, ki so se odvijale predvsem v času med letoma 1876 in 1882 . V tem obdobju so iz repertoarja izginila predvsem dela številnih skladateljev, katerih najpomembnejše ustvarjalno obdobje sodi v prvo polovico 19. stoletja. Tako so bili izločeni skoraj vsi skladatelji, katerih dela so bila $\mathrm{v}$ arhivu stolnega kora pred Foersterjevim prihodom (J. Blachak, H. von Bombelles, J. Kloss, G. Mašek, A. Rieder), pa tudi številni drugi, ki so bili zastopani z večinoma po eno ali dvema skladbama (K. Doblhof-Dier, E. Frey, R. Führer, H. G. Götz, K. Jaspers, B. Kothe, C. G. Lickl, L. E. Mechura, F. Mendelssohn, G. Meyerbeer, J. B. Müller, R. Musiol, Ch. H. Rieder, G. V. Röder, F. X. Schmidt, J. Seiler, J. Stern, J. B. Sturm, I. Traumichler in H. Vollmar). Med njimi so bili celo taki avtorji, ki so v svojem času veljali za začetnike cerkvenoglasbene reforme (npr. K. L. Drobisch). Na drugi strani se je povečalo število izvajanih skladb že poprej zastopanih vodilnih cecilijanskih avtorjev, po letu 1886 pa so bili v repertoar vključeni tudi mlajši nemški (J. Gruber, J. Renner, K. Santner, I. Mitterer, B. Stein), češki (J. N. Škroup, F. Z. Skuhersky) in slovenski cecilijanski ustvarjalci (J. Lavtižar, I. Hladnik, p. H. Sattner). Tudi pri teh, na novo vključenih skladbah so zastopane vse smeri cecilijanske ustvarjalnosti, vendar je opazna številčna premoč tiste, ki se je nagibala k približevanju sodobnemu glasbenemu jeziku (J. Gruber, K. Santner, J. N. Škroup). Malenkostno se je povečal tudi izbor del avtorjev iz 16. stoletja (Palestrina, Gallus).

Če poskušamo na koncu strniti naše ugotovitve o temeljnih potezah izvajanega repertoarja na koru ljubljanske stolnice v času Foersterjevega rektorovanja, lahko ugotovimo, da se nakazujeta dve dokaj jasno ločeni obdobji. V prvem, ki traja od nastopa 
službe 1868 do ok. leta 1876, je Foerster z novooblikovanim zborom naštudiral velikanski repertoar skladb na latinska besedila, ki je bil potreben za izvajanje z liturgičnimi predpisi skladne cerkvene glasbe. Pri tem se je dokaj uravnovešeno opiral na tri vire:

a) na produkcijo prve polovice 19. stoletja, zlasti na avtorje, ki so si že v tem času prizadevali za resnobnejšo cerkveno glasbo. Pri tem so imeli očitno pomembno vlogo njegovo šolanje in stiki z domovino, saj najdemo med zastopanimi skladatelji nesorazmerno veliko skladateljev, ki so delovali na Češkem,

b) na historični repertoar skladb 16. in 17. stol., ki je ob koralu veljal za ideal cerkvene glasbe (deloma jih je črpal iz zbirke Musica sacra, ki je bila ob njegovem prihodu že v arhivu stolnega kora). S tem je slovenski javnosti prvič predstavil številna dela historičnega repertoarja in - čeprav v strogo funkcionalno omejeni vlogi - prispeval $\mathrm{k}$ oživitvi glasbe preteklih stoletij,

c) na zgodnjo cecilijansko produkcijo, ki jo je propagiralo zlasti nemško strokovno časopisje in katero je bogato dopolnil tudi s svojimi deli. Pri tem je pokazal izredno širino, saj se ni priključil nobeni od smeri, ki so se izoblikovale znotraj cecilijanskega gibanja.

V letih, ko se je tudi na Slovenskem močneje razmahnilo cecilijansko gibanje in dobilo tudi trdnejši organizacijski okvir (po 1877), je tudi repertoar stolnega kora, najpomembnejše tovrstne ustanove, doživljal - ob sorazmerni stalnosti - nekaj sprememb. Foerster si je prizadeval za njegovo dokončno uskladitev s cecilijanskimi merili ter je zato izločil precejšnji del skladb avtorjev iz prve polovice 19. stoletja. Nadomestile so jih predvsem skladbe skladateljev, ki so bili tesno povezani s cecilijanskim gibanjem. V zadnjih letih (po 1901) lahko zaznamo nekoliko večjo naklonjenost naprednejšim skladateljem münchenskega in avstrijskega kroga, kar sovpada s postopnim opuščanjem ozkosrčnih staroceciijanskih meril ter uveljavitvijo mladocecilijanskih idej in repertoarja v slovenskem prostoru. Tako stanje je ostajalo nespremenjeno vse do njegovega odhoda leta 1908.

\section{Tabela 2}

\begin{tabular}{|c|c|c|c|c|c|c|c|c|c|c|}
\hline & & 1876 & $\begin{array}{c}\text { VEL. } \\
\text { NOČ } \\
1880\end{array}$ & $\begin{array}{l}\text { ZAČ. } \\
1882\end{array}$ & \begin{tabular}{|l} 
VEL. \\
NOČ \\
1882
\end{tabular} & \begin{tabular}{|l|} 
VEL. \\
NOČ \\
1883
\end{tabular} & 1886 & $\begin{array}{c}\text { BOŽıČ } \\
1887\end{array}$ & 1891 & 1901 \\
\hline \multicolumn{11}{|l|}{ Maše } \\
\hline Bauer[, Joseph] & [Neznana maša] & & & & & & {$[\mathrm{X}]$} & & & $\mathrm{X}$ \\
\hline $\begin{array}{l}\text { Benz, J[ohann] } \\
\text { B[aptist] }\end{array}$ & $\begin{array}{l}\text { Missa [»O clemens, o pia«] v } \\
\text { F-duru, op. } 8\end{array}$ & $\mathrm{X}$ & & {$[\mathrm{X}]$} & & $\mathrm{X}$ & {$[\mathrm{X}]$} & & & {$[\mathrm{X}]$} \\
\hline $\begin{array}{l}\text { Benz, J[ohann] } \\
\text { B[aptist] }\end{array}$ & Missa s. Caeciliae, op. 15 & $\mathrm{X}$ & $\mathrm{X}$ & {$[\mathrm{X}]$} & & & {$[\mathrm{X}]$} & $\mathrm{X}$ & & {$[\mathrm{X}]$} \\
\hline Bröer, E[rnst] & Maša št. 6 v C-duru* & $\mathrm{X}$ & & {$[\mathrm{X}]$} & & & {$[\mathrm{X}]$} & & & {$[\mathrm{X}]$} \\
\hline Brosig, $\mathrm{M}$ [oritz] & Maša v f-molu, op. $31^{*}$ & $\mathrm{X}$ & & {$[\mathrm{X}]$} & & & {$[\mathrm{X}]$} & & & {$[\mathrm{X}]$} \\
\hline Brosig, M[oritz] & Missa IV & & & & & $\mathrm{X}$ & {$[\mathrm{X}]$} & & & {$[\mathrm{X}]$} \\
\hline Cannicciari[, D.] & [Missa in a] & & & & & & & & & {$[\mathrm{X}]$} \\
\hline $\begin{array}{l}\text { Ett, [Joseph] } \\
\text { Kasp[ar] }\end{array}$ & Koralna maša z orglami & $\mathrm{X}$ & & {$[\mathrm{X}]$} & & & {$[\mathrm{X}]$} & & & {$[\mathrm{X}]$} \\
\hline Foerster, A[nton] & Missa s. Caeciliae & & $\mathrm{X}$ & {$[\mathrm{X}]$} & & & {$[\mathrm{X}]$} & $\mathrm{X}$ & & {$[\mathrm{X}]$} \\
\hline
\end{tabular}




\begin{tabular}{|c|c|c|c|c|c|c|c|c|c|c|}
\hline & & 1876 & \begin{tabular}{|l|} 
VEL. \\
NOČ \\
1880
\end{tabular} & $\begin{array}{l}\text { ZAČ. } \\
1882\end{array}$ & \begin{tabular}{|l} 
VEL. \\
NOČ \\
1882
\end{tabular} & \begin{tabular}{|l|} 
VEL. \\
NOČ \\
1883
\end{tabular} & 1886 & $\begin{array}{c}\text { BOŽIČ } \\
1887\end{array}$ & 1891 & 1901 \\
\hline Foerster, Ant[on] & $\begin{array}{l}\text { Slavnostna maša, op. } 25 \text { (z } \\
\text { instrumenti) }\end{array}$ & & & & & & & $\mathrm{X}$ & & {$[\mathrm{X}]$} \\
\hline $\begin{array}{l}\text { Förster [=Foerster], } \\
\mathrm{A}[\text { nton] }\end{array}$ & Maša v C-duru & $\mathrm{X}$ & & {$[\mathrm{X}]$} & & & {$[\mathrm{X}]$} & & & {$[\mathrm{X}]$} \\
\hline $\begin{array}{l}\text { Förster [=Foerster }], \\
\mathrm{A}[\text { nton] }\end{array}$ & Missa in a & $\mathrm{X}$ & & {$[\mathrm{X}]$} & & & {$[\mathrm{X}]$} & & & {$[\mathrm{X}]$} \\
\hline $\begin{array}{l}\text { Förster [=Foerster], } \\
\text { A[nton] }\end{array}$ & $\begin{array}{l}\text { Maša v G-duru »Ex variis } \\
\text { canticis« }\end{array}$ & $\mathrm{X}$ & & {$[\mathrm{X}]$} & & & {$[\mathrm{X}]$} & & & {$[\mathrm{X}]$} \\
\hline $\begin{array}{l}\text { Förster [=Foerster], } \\
\text { A[nton] }\end{array}$ & $\begin{array}{l}\text { Missa s. Aloysii v D-duru } \\
\text { (moški zbor) }\end{array}$ & $\mathrm{X}$ & & {$[\mathrm{X}]$} & & & {$[\mathrm{X}]$} & & & {$[\mathrm{X}]$} \\
\hline Förster, Jos[eph] & Maša s. Adalberti, op. 31 & $\mathrm{X}$ & & {$[\mathrm{X}]$} & & & {$[\mathrm{X}]$} & $\mathrm{X}$ & & {$[\mathrm{X}]$} \\
\hline Gallus, Jacobus & $\begin{array}{l}\text { Missa Elisabeth Zachariae (prir. } \\
\text { Foerster) }\end{array}$ & & & & & & & & & {$[\mathrm{X}]$} \\
\hline Greith, Karl & Maša v D-duru & $\mathrm{X}$ & $\mathrm{X}$ & {$[\mathrm{X}]$} & & & {$[\mathrm{X}]$} & & & {$[\mathrm{X}]$} \\
\hline Greith, Karl & Maša v F-duru, op. 13 & $\mathrm{X}$ & & {$[\mathrm{X}]$} & & & {$[\mathrm{X}]$} & & & {$[\mathrm{X}]$} \\
\hline Greith, Karl & Missa s. Josephi, op. 16 & $\mathrm{X}$ & & {$[\mathrm{X}]$} & & $\mathrm{X}$ & {$[\mathrm{X}]$} & & & {$[\mathrm{X}]$} \\
\hline Greith, Karl & 3. koralna maša & $\mathrm{X}$ & & {$[\mathrm{X}]$} & & & {$[\mathrm{X}]$} & & & {$[\mathrm{X}]$} \\
\hline Greith, Karl & 4. koralna maša, op. 10 & $\mathrm{X}$ & & {$[\mathrm{X}]$} & & & {$[\mathrm{X}]$} & & & {$[\mathrm{X}]$} \\
\hline Gruber[, Joseph] & [Neznana maša] & & & & & & & & & $\mathrm{X}$ \\
\hline Hahn, B[ernhard] & Maša št. $3 \mathrm{v}$ a-molu* & $\mathrm{X}$ & & {$[\mathrm{X}]$} & & & {$[\mathrm{X}]$} & $\mathrm{X}$ & & {$[\mathrm{X}]$} \\
\hline Hahn, B[ernhard] & Maša št. 4 v C-duru* & $\mathrm{X}$ & & {$[\mathrm{X}]$} & & & {$[\mathrm{X}]$} & & & {$[\mathrm{X}]$} \\
\hline Haller, Michael & [Neznana maša] & & & & & & {$[\mathrm{X}]$} & & & $\mathrm{X}$ \\
\hline $\begin{array}{l}\text { Hasler, Joh }[\text { ann }= \\
\text { Haßler, Hans Leo] }\end{array}$ & Missa secunda & $\mathrm{X}$ & & {$[\mathrm{X}]$} & & & {$[\mathrm{X}]$} & & & {$[\mathrm{X}]$} \\
\hline Hladnik[, Ignacij] & [Missa solemnis op. 38] & & & & & & & & & {$[\mathrm{X}]$} \\
\hline \begin{tabular}{|l|} 
Horack, W[enzel] \\
E[manuel]
\end{tabular} & Maša št. $6 \mathrm{v}$ d-molu* & $\mathrm{X}$ & & {$[\mathrm{X}]$} & & & {$[\mathrm{X}]$} & & & {$[\mathrm{X}]$} \\
\hline Hribar[, Angelik] & $\begin{array}{l}\text { [Missa »Tota pulchra es, } \\
\text { Maria«] }\end{array}$ & & & & & & & & & {$[\mathrm{X}]$} \\
\hline Jaspers, K[arl] & Missa B. M. V. consol. afflict. & $\mathrm{X}$ & & - & & & - & & & - \\
\hline Joos, O[swald] & [Missa in D, op. 11] & & & & & & {$[\mathrm{X}]$} & & & {$[\mathrm{X}]$} \\
\hline Kaim, Ad. & Missa s. Caeciliae & & $\mathrm{X}$ & {$[\mathrm{X}]$} & & & {$[\mathrm{X}]$} & & & {$[\mathrm{X}]$} \\
\hline Kaim, Ad. & Missa » Jesu redemptor" & $\mathrm{X}$ & & {$[\mathrm{X}]$} & $\mathrm{X}$ & & {$[\mathrm{X}]$} & & & {$[\mathrm{X}]$} \\
\hline Kempter, Karl & Maša v D-duru* & $\mathrm{X}$ & & {$[\mathrm{X}]$} & & & {$[\mathrm{X}]$} & & & {$[\mathrm{X}]$} \\
\hline Koenen, F. & [Neznana maša] & & & & & & {$[\mathrm{X}]$} & & & $\mathrm{X}$ \\
\hline Krawutschke[, Rob.] & [Missa de ss. Nomine Jesu] & & & & & & {$[\mathrm{X}]$} & & & {$[\mathrm{X}]$} \\
\hline Krenn, $\operatorname{Fr}[\mathrm{anz}]$ & Maša v a-molu, op. $40^{*}$ & $\mathrm{X}$ & & & & & {$[\mathrm{X}]$} & & & - \\
\hline $\begin{array}{l}\text { Mettenleiter, } \\
\text { B[ernhard] }\end{array}$ & Maša op. 15, »Preis-Messe« & $\mathrm{X}$ & & {$[\mathrm{X}]$} & & & {$[\mathrm{X}]$} & & & {$[\mathrm{X}]$} \\
\hline Mitterer, Ignaz & [Neznana maša] & & & & & & & & & $\mathrm{X}$ \\
\hline Nešvera, Josef & $\begin{array}{l}\text { [Missa in hon. s. Friderici, } \\
\text { op. 60] }\end{array}$ & & & & & & & & & {$[\mathrm{X}]$} \\
\hline Palestrina & [Neznana maša] & & & & & & & & & $\mathrm{X}$ \\
\hline
\end{tabular}


A. Nagode: Poskus rekonstrukcije latinskih cerkvenih skladb na koru ljubljanske stolnice ...

\begin{tabular}{|c|c|c|c|c|c|c|c|c|c|c|}
\hline & & 1876 & \begin{tabular}{c|} 
VEL. \\
NOČ \\
1880
\end{tabular} & \begin{tabular}{|l|} 
ZAČ. \\
1882
\end{tabular} & \begin{tabular}{|c|} 
VEL. \\
NOČ \\
1882
\end{tabular} & \begin{tabular}{|l|} 
VEL. \\
NOČ \\
1883
\end{tabular} & 1886 & $\begin{array}{c}\text { BOŽIČ } \\
1887\end{array}$ & 1891 & 1901 \\
\hline Rampis, P. & $\begin{array}{l}\text { Missa Cuniberti (prirejena za } \\
\text { instrumentalno spremljavo) }\end{array}$ & $\mathrm{X}$ & & {$[\mathrm{X}]$} & $\mathrm{X}$ & & {$[\mathrm{X}]$} & & & {$[\mathrm{X}]$} \\
\hline Rampis, P. & $\begin{array}{l}\text { Missa s. Wilibaldi (za } 3 \text { moške } \\
\text { glasove) }\end{array}$ & $\mathrm{X}$ & & {$[\mathrm{X}]$} & & & {$[\mathrm{X}]$} & & & {$[\mathrm{X}]$} \\
\hline Santner, K[arl] & [Neznana maša] & & & & & & {$[\mathrm{X}]$} & & & $\mathrm{X}$ \\
\hline \begin{tabular}{|l} 
Schaller, \\
F[erdinand] \\
\end{tabular} & Missa »Salve Regina» & & & {$[\mathrm{X}]$} & $\mathrm{X}$ & & {$[\mathrm{X}]$} & & & {$[\mathrm{X}]$} \\
\hline Schöpf, [Franz] & Missa s. Caeciliae & & & {$[\mathrm{X}]$} & $\mathrm{X}$ & & {$[\mathrm{X}]$} & & & {$[\mathrm{X}]$} \\
\hline Schweitzer, J[ohann] & Missa ss. angelorum custodum & & & & $\mathrm{X}$ & & {$[\mathrm{X}]$} & & & {$[\mathrm{X}]$} \\
\hline $\begin{array}{l}\text { Skuhersky, } \\
\text { F[rantišek Zdenek] }\end{array}$ & [Neznana maša] & & & & & & & & & $\mathrm{X}$ \\
\hline Stehle, G. E. & Preismesse »Salve regina« & $\mathrm{X}$ & & {$[\mathrm{X}]$} & & & {$[\mathrm{X}]$} & & & {$[\mathrm{X}]$} \\
\hline Stein, B[runo] & [Neznana maša] & & & & & & & & & $\mathrm{X}$ \\
\hline $\begin{array}{l}\begin{array}{l}\text { Škroup, J[an Nepo- } \\
\text { muk] }\end{array} \\
\end{array}$ & Missa IV & & & & $\mathrm{X}$ & $\mathrm{X}$ & {$[\mathrm{X}]$} & & & {$[\mathrm{X}]$} \\
\hline $\begin{array}{l}\begin{array}{l}\text { Škroup, J an Nepo- } \\
\text { muk] }\end{array} \\
\end{array}$ & [Missa I in $\mathrm{g}$ ali Missa II in B] & & & & & $\mathrm{X}$ & {$[\mathrm{X}]$} & & & {$[\mathrm{X}]$} \\
\hline Uhl, Fel[ix] & Missa op. 8 v F-duru & $\mathrm{X}$ & & {$[\mathrm{X}]$} & & & {$[\mathrm{X}]$} & & & {$[\mathrm{X}]$} \\
\hline Witt, Fr[anz X.] & Maša »Exultet«, op. 9 & $\mathrm{X}$ & & {$[\mathrm{X}]$} & & & {$[\mathrm{X}]$} & $\mathrm{X}$ & & {$[\mathrm{X}]$} \\
\hline Witt, $\operatorname{Fr}[\operatorname{anz} \mathrm{X}]$. & Missa s. Luciae, op. 11 & $\mathrm{X}$ & & {$[\mathrm{X}]$} & & & {$[\mathrm{X}]$} & & & {$[\mathrm{X}]$} \\
\hline Witt, Fr[anz X.] & Missa op. 18 »s. Augustini« & $\mathrm{X}$ & & {$[\mathrm{X}]$} & & & {$[\mathrm{X}]$} & & & {$[\mathrm{X}]$} \\
\hline \multirow{2}{*}{$\begin{array}{l}\text { Zangl, Jos[eph } \\
\text { Gregor] }\end{array}$} & Maša v C-dur, op. 29 & $\mathrm{X}$ & & {$[\mathrm{X}]$} & & & {$[\mathrm{X}]$} & & & {$[\mathrm{X}]$} \\
\hline & $\begin{array}{l}\text { Število neidentificiranih } \\
\text { maš }\end{array}$ & & & 8 & & & 8 & & 60 & $>15$ \\
\hline \multicolumn{11}{|l|}{ Requiemi } \\
\hline Bauer[, Joseph] & [Requiem] & & & & & & {$[\mathrm{X}]$} & & & {$[\mathrm{X}]$} \\
\hline Bibl, R[udolf] & [Requiem in d, op. 84] & & & & & & & & & {$[\mathrm{X}]$} \\
\hline \begin{tabular}{|l|} 
Ett, [Joseph] \\
Kasp[ar]
\end{tabular} & Koral z orglami & $\mathrm{x}$ & & {$[\mathrm{X}]$} & & & {$[\mathrm{X}]$} & & & - \\
\hline $\begin{array}{l}\text { Förster [=Foerster], } \\
\mathrm{A}[\text { nton] }\end{array}$ & Requiem v d-molu[, op. 20] & $\mathrm{X}$ & & {$[\mathrm{X}]$} & & & {$[\mathrm{X}]$} & & & {$[\mathrm{X}]$} \\
\hline Greith, Karl & $\begin{array}{l}\text { Requiem za } 1 \text { glas z orglami } \\
\text { [op. 15] (prirejeno po njegovi } \\
\text { orgelski zbirki) }\end{array}$ & $\mathrm{X}$ & & {$[\mathrm{X}]$} & & & {$[\mathrm{X}]$} & & & {$[\mathrm{X}]$} \\
\hline Gruber[, Josef] & [Requiem V. in g, op. 150] & & & & & & & & & {$[\mathrm{X}]$} \\
\hline Haller[, Michael] & [Requiem in Es] & & & & & & {$[\mathrm{X}]$} & & & {$[\mathrm{X}]$} \\
\hline Hladnik[, Ignacij] & [Requiem in F, op. 2] & & & & & & & & & {$[\mathrm{X}]$} \\
\hline Hribar[, Angelik] & [Requiem in a] & & & {$[\mathrm{X}]$} & & & {$[\mathrm{X}]$} & & & {$[\mathrm{X}]$} \\
\hline $\begin{array}{l}\text { Maschek, Kasp[ar } \\
=\text { Mašek, Gašper] }\end{array}$ & Requiem v d-molu[, op. 97] ${ }^{*}$ & $\mathrm{X}$ & & - & & & - & & & - \\
\hline $\begin{array}{l}\text { Maschek, Kasp[ar } \\
=\text { Mašek, Gašper] }\end{array}$ & Requiem v g-molu* & $\mathrm{X}$ & & - & & & - & & & - \\
\hline
\end{tabular}




\begin{tabular}{|c|c|c|c|c|c|c|c|c|c|c|}
\hline & & 1876 & $\begin{array}{l}\text { VEL. } \\
\text { NOĆ } \\
1880 \\
\end{array}$ & $\begin{array}{l}\text { ZAČ. } \\
1882\end{array}$ & $\begin{array}{l}\text { VEL. } \\
\text { NOČ } \\
1882\end{array}$ & $\begin{array}{l}\text { VEL. } \\
\text { NOCC } \\
1883\end{array}$ & 1886 & $\begin{array}{c}\text { BOŽIIČ } \\
1887\end{array}$ & 1891 & 1901 \\
\hline $\begin{array}{l}\text { Mettenleiter, } \\
\text { B[ernhard] }\end{array}$ & Requiem v F-duru* & $\mathrm{X}$ & & {$[\mathrm{X}]$} & & & {$[\mathrm{X}]$} & & & {$[\mathrm{X}]$} \\
\hline \begin{tabular}{|l} 
Obersteiner[, \\
Johann]
\end{tabular} & [Requiem in F] & & & {$[\mathrm{X}]$} & & & {$[\mathrm{X}]$} & & & {$[\mathrm{X}]$} \\
\hline Panny, Jos[eph] & Requiem in Es-duru, op. 21 & $\mathrm{X}$ & & & & & - & & & {$[\mathrm{X}]$} \\
\hline Renner[, Josef] & [Requiem III in D, op. 43] & & & & & & {$[\mathrm{X}]$} & & & {$[\mathrm{X}]$} \\
\hline Santner[, Karl] & [Requiem in a] & & & & & & {$[\mathrm{X}]$} & & & {$[\mathrm{X}]$} \\
\hline $\begin{array}{l}\text { Schenck, A[lbert] } \\
\text { D[avid] } \\
\end{array}$ & Requiem v d-molu & $\mathrm{X}$ & & {$[\mathrm{X}]$} & & & {$[\mathrm{X}]$} & & & {$[\mathrm{X}]$} \\
\hline \multirow[t]{2}{*}{ Stein[, Bruno] } & [Requiem] & & & & & & & & & {$[\mathrm{X}]$} \\
\hline & $\begin{array}{l}\text { Število neidentificiranih } \\
\text { requiemov }^{* *}\end{array}$ & & & 2 & & & 1 & & 13 & 0 \\
\hline \multicolumn{11}{|l|}{ Moteti } \\
\hline \begin{tabular}{|l|} 
Aiblinger, [Johann] \\
Kasp[ar]
\end{tabular} & Jubilate (5 gl.) & $\mathrm{X}$ & & {$[\mathrm{X}]$} & & & {$[\mathrm{X}]$} & & & \\
\hline $\begin{array}{l}\text { Aiblinger, [Johann] } \\
\text { Kasp[ar] }\end{array}$ & Veni Sancte Spiritus (5 gl.) & $\mathrm{X}$ & & {$[\mathrm{X}]$} & & & {$[\mathrm{X}]$} & & & \\
\hline $\begin{array}{l}\text { Aiblinger, [Johann] } \\
\text { Kasp[ar] }\end{array}$ & Ave Maria v a-molu (6 gl.) & $\mathrm{X}$ & & {$[\mathrm{X}]$} & & & {$[\mathrm{X}]$} & & & \\
\hline \begin{tabular}{|l|} 
Aiblinger, [Johann] \\
Kasp[ar]
\end{tabular} & Assumpta est ( $3 \mathrm{gl}$.) & $\mathrm{x}$ & & {$[\mathrm{X}]$} & & & {$[\mathrm{X}]$} & & & \\
\hline Allegri, Gr[egorio] & Miserere (dvozborsko) & $\mathrm{x}$ & $\mathrm{X}$ & {$[\mathrm{X}]$} & & $\mathrm{X}$ & {$[\mathrm{X}]$} & & & \\
\hline Anonimni & O salutaris hostia & & & & & & & $\mathrm{X}$ & & \\
\hline Antonelli, Abundio & Quem vidistis & $\mathrm{X}$ & & {$[\mathrm{X}]$} & & & - & & & \\
\hline Baini[, Giuseppe] & Panis angelicus ( 3 gl.) & $\mathrm{X}$ & & {$[\mathrm{X}]$} & & & - & & & \\
\hline $\begin{array}{l}\text { Benz, J[ohann] } \\
\text { B[aptist] }\end{array}$ & $\begin{array}{l}\text { Šest motetov op. } 10 \\
\text {-Tecum principium } \\
\text {-Hodie }\end{array}$ & $\mathrm{X}$ & & {$[\mathrm{X}]$} & & & {$[\mathrm{X}]$} & $\begin{array}{l}\mathrm{X} \\
\mathrm{X}\end{array}$ & & \\
\hline $\begin{array}{l}\text { Blachak, Joh. [=Jo- } \\
\text { seph] }\end{array}$ & $\begin{array}{l}\text { Christus natus, op. } 10 \text { ( } 5 \text { gl. } \mathrm{z} \\
\text { orglami) }\end{array}$ & $\mathrm{X}$ & & - & & & - & & & \\
\hline $\begin{array}{l}\text { Bombelles, H. Gr. } \\
\text { von }\end{array}$ & Ave Maria & $\mathrm{X}$ & & - & & & - & & & \\
\hline $\begin{array}{l}\text { Bombelles, H. Gr. } \\
\text { von }\end{array}$ & Memorare & $\mathrm{X}$ & & - & & & - & & & \\
\hline Brosig, Mor[itz] & Veni s. Spiritus (z instrumenti) & $\mathrm{X}$ & & {$[\mathrm{X}]$} & & & {$[\mathrm{X}]$} & & & \\
\hline Burgarell[, Robert] & Ofertorij za 4. adventno nedeljo & $\mathrm{X}$ & & - & & & {$[\mathrm{X}]$} & & & \\
\hline $\begin{array}{l}\text { Casciolini[, Cla- } \\
\text { udio] }\end{array}$ & Angelus Domini (dvozborski) & $\mathrm{X}$ & & {$[\mathrm{X}]$} & & & {$[\mathrm{X}]$} & & & \\
\hline \begin{tabular}{|l|}
$\begin{array}{l}\text { Cordans [, Bartolo- } \\
\text { meo] }\end{array}$ \\
\end{tabular} & Alme Deus (3 gl.) & $\mathrm{X}$ & & {$[\mathrm{X}]$} & & & {$[\mathrm{X}]$} & & & \\
\hline \begin{tabular}{|l} 
Doblhof-Dier[, \\
Karl]
\end{tabular} & Circumdederunt me & $\mathrm{X}$ & & - & & & - & & & \\
\hline $\begin{array}{l}\text { Doblhof-Dier[, } \\
\text { Karl] }\end{array}$ & In horrore & $\mathrm{X}$ & & - & & & - & & & \\
\hline
\end{tabular}


A. Nagode: Poskus rekonstrukcije latinskih cerkvenih skladb na koru ljubljanske stolnice ...

\begin{tabular}{|c|c|c|c|c|c|c|c|c|c|c|}
\hline & & 1876 & \begin{tabular}{c|} 
VEL. \\
NOČ \\
1880
\end{tabular} & $\begin{array}{l}\text { ZAČ. } \\
1882\end{array}$ & $\begin{array}{l}\text { VEL. } \\
\text { NOČ } \\
1882\end{array}$ & \begin{tabular}{|l|} 
VEL. \\
NOČ \\
1883
\end{tabular} & 1886 & $\begin{array}{c}\text { BOŽIČ } \\
1887\end{array}$ & 1891 & 1901 \\
\hline $\begin{array}{l}\text { Drobisch, K[arl] } \\
\text { L[udwig] }\end{array}$ & Beatus vir & $\mathrm{X}$ & & - & & & - & & & \\
\hline $\begin{array}{l}\text { Drobisch, K[arl] } \\
\text { L[udwig] }\end{array}$ & Magna et mirabilia & $\mathrm{X}$ & & - & & & - & & & \\
\hline $\begin{array}{l}\text { Drobisch, K[arl] } \\
\text { L[udwig] }\end{array}$ & Levavi animam ( $\mathrm{z}$ instrumenti) & $\mathrm{x}$ & & - & & & - & & & \\
\hline \begin{tabular}{|l|} 
Ett, [Joseph] \\
Kasp[ar]
\end{tabular} & Laudate pueri & $\mathrm{X}$ & & {$[\mathrm{X}]$} & & & {$[\mathrm{X}]$} & & & \\
\hline $\begin{array}{l}\text { Ett, [Joseph] } \\
\text { Kasp[ar] }\end{array}$ & $\begin{array}{l}\text { Laudate Dominum (dvozbor- } \\
\text { ski) }\end{array}$ & $\mathrm{x}$ & & {$[\mathrm{X}]$} & & & {$[\mathrm{X}]$} & & & \\
\hline \begin{tabular}{|l|} 
Ett, [Joseph] \\
Kasp[ar]
\end{tabular} & Te Joseph celebrent & $\mathrm{X}$ & & {$[\mathrm{X}]$} & & & {$[\mathrm{X}]$} & & & \\
\hline $\begin{array}{l}\text { Förster [=Foerster], } \\
\text { A[nton] }\end{array}$ & Ad te levavi (moški zbor) & $\mathrm{X}$ & & {$[\mathrm{X}]$} & & & {$[\mathrm{X}]$} & & & \\
\hline $\begin{array}{l}\text { Förster [=Foerster], } \\
\mathrm{A}[\text { nton] }\end{array}$ & Dextera Domini & $\mathrm{X}$ & & {$[\mathrm{X}]$} & & & {$[\mathrm{X}]$} & & & \\
\hline $\begin{array}{l}\text { Förster [=Foerster], } \\
\mathrm{A}[\text { nton] }\end{array}$ & $\begin{array}{l}\text { Domine in auxilium (solo z } \\
\text { orglami) }\end{array}$ & $\mathrm{X}$ & & {$[\mathrm{X}]$} & & & {$[\mathrm{X}]$} & & & \\
\hline $\begin{array}{l}\text { Förster [=Foerster], } \\
\text { A[nton] }\end{array}$ & Ecce sacerdos (z instrumenti) & $\mathrm{X}$ & & {$[\mathrm{X}]$} & & & {$[\mathrm{X}]$} & & & \\
\hline Foerster[, Anton] & $\begin{array}{l}\text { Gradual in Trakt za ponedeljek } \\
\text { pred veliko nočjo }\end{array}$ & & & & & $\mathrm{X}$ & {$[\mathrm{X}]$} & & & \\
\hline Foerster[, Anton] & Gradual za belo nedeljo & & & & & & {$[\mathrm{X}]$} & & & \\
\hline Foerster[, Anton] & Gradual za praznik sv. Štefana & & & & & & & $\mathrm{X}$ & & \\
\hline $\begin{array}{l}\text { Förster [=Foerster], } \\
\mathrm{A}[\text { nton] }\end{array}$ & $\begin{array}{l}\text { Grad. in Offert. in assumpt. } \\
\text { BMV }\end{array}$ & $\mathrm{X}$ & & {$[\mathrm{X}]$} & & & {$[\mathrm{X}]$} & & & \\
\hline $\begin{array}{l}\text { Förster [=Foerster], } \\
\text { A[nton] }\end{array}$ & Illumina oculos (moški zbor) & $\mathrm{X}$ & & {$[\mathrm{X}]$} & & & {$[\mathrm{X}]$} & & & \\
\hline Foerster[, Anton] & Lamentacije & & $\mathrm{X}$ & {$[\mathrm{X}]$} & $\mathrm{X}$ & $\mathrm{X}$ & {$[\mathrm{X}]$} & & & \\
\hline Foerster[, Anton] & Očitanje & & $\mathrm{X}$ & {$[\mathrm{X}]$} & & $\mathrm{X}$ & {$[\mathrm{X}]$} & & & \\
\hline Foerster[, Anton] & Ofertorij za praznik sv. Štefana & & & & & & & $\mathrm{X}$ & & \\
\hline Foerster[, Anton] & Ofertorij za veliki četrtek & & & & $\mathrm{X}$ & $\mathrm{X}$ & {$[\mathrm{X}]$} & & & \\
\hline Foerster[, Anton] & $\begin{array}{l}\text { Ofertorij za veliko nedeljo } \\
\text { »Terra tremuit« }\end{array}$ & & $\mathrm{X}$ & {$[\mathrm{X}]$} & $\mathrm{X}$ & $\mathrm{X}$ & {$[\mathrm{X}]$} & & & \\
\hline $\begin{array}{l}\text { Förster [=Foerster], } \\
\text { A[nton] }\end{array}$ & Omnes de Saba & $\mathrm{x}$ & & {$[\mathrm{X}]$} & & & {$[\mathrm{X}]$} & & & \\
\hline $\begin{array}{l}\text { Förster [=Foerster], } \\
\text { A[nton] }\end{array}$ & Pater noster (moški zbor) & $\mathrm{x}$ & & {$[\mathrm{X}]$} & & & {$[\mathrm{X}]$} & & & \\
\hline Foerster[, Anton] & Sicut ovis (3 gl. ženski zbor) & & & & $\mathrm{X}$ & $\mathrm{X}$ & {$[\mathrm{X}]$} & & & \\
\hline Foerster[, Anton] & Tamquam ad latronem & & & & $\mathrm{X}$ & & {$[\mathrm{X}]$} & & & \\
\hline $\begin{array}{l}\text { Förster [=Foerster], } \\
\text { A[nton] }\end{array}$ & Veni sancte spiritus (a-mol) & $\mathrm{X}$ & & {$[\mathrm{X}]$} & & & {$[\mathrm{X}]$} & & & \\
\hline $\begin{array}{l}\text { Förster [=Foerster], } \\
\text { A[nton] }\end{array}$ & $\begin{array}{l}\text { Veni sancte spiritus (D-dur) (z } \\
\text { instrumenti) }\end{array}$ & $\mathrm{X}$ & & {$[\mathrm{X}]$} & & & {$[\mathrm{X}]$} & & & \\
\hline
\end{tabular}




\begin{tabular}{|c|c|c|c|c|c|c|c|c|c|c|}
\hline & & 1876 & \begin{tabular}{|l} 
VEL. \\
NOĆ \\
1880
\end{tabular} & $\begin{array}{l}\text { ZAČ. } \\
1882\end{array}$ & \begin{tabular}{|l} 
VEL. \\
NOCC \\
1882
\end{tabular} & \begin{tabular}{|l} 
VEL. \\
NOCC \\
1883
\end{tabular} & 1886 & $\begin{array}{c}\text { BOŽIČ } \\
1887\end{array}$ & 1891 & 1901 \\
\hline $\begin{array}{l}\text { Förster [=Foerster], } \\
\text { A[nton] }\end{array}$ & Veritas mea & $\mathrm{X}$ & & {$[\mathrm{X}]$} & & & {$[\mathrm{X}]$} & $\mathrm{X}$ & & \\
\hline Foerster, Anton & $\begin{array}{l}\text { Razni moteti iz zbirke Gradu- } \\
\text { alia itd. }\end{array}$ & & & & & & & & & $\mathrm{X}$ \\
\hline Förster, Jos[eph] & $\begin{array}{l}4 \text { graduali za adventne nedelje, } \\
\text { op. } 21\end{array}$ & $\mathrm{X}$ & & {$[\mathrm{X}]$} & & & {$[\mathrm{X}]$} & $\mathrm{X}$ & & \\
\hline Frey, Eug[en] & Adoro te & $\mathrm{X}$ & & & & & - & & & \\
\hline Führer, Rob[ert] & $\begin{array}{l}\text { Grad. in Offert. in assumpt. B. } \\
\text { M. V. (prirejena in brez instru- } \\
\text { mentov) }\end{array}$ & $\mathrm{X}$ & & {$[\mathrm{X}]$} & & & - & & & \\
\hline Gallus, Jacobus & Ascendo (6 gl.) & $\mathrm{X}$ & & {$[\mathrm{X}]$} & & & {$[\mathrm{X}]$} & & & \\
\hline Gallus, Jacobus & Ecce quomodo moritur iustus & & & & & $\mathrm{X}$ & {$[\mathrm{X}]$} & & & \\
\hline Gallus, Jacobus & In nomine Jesu & $\mathrm{X}$ & & {$[\mathrm{X}]$} & & & {$[\mathrm{X}]$} & & & \\
\hline \begin{tabular}{|l|} 
Gänsbacher, \\
Joh[ann Baptist]
\end{tabular} & 3 Ave Maria in 1 Ave regina & $\mathrm{X}$ & & {$[\mathrm{X}]$} & & & - & & & \\
\hline $\begin{array}{l}\text { Götz[, Hermann } \\
\text { Gustav] }\end{array}$ & Exaudi Domine & $\mathrm{X}$ & & - & & & - & & & \\
\hline Greith, Karl & $\begin{array}{l}\text { Ave Maria op. } 19 \text { ( } 3 \text { gl. z } \\
\text { orglami) }\end{array}$ & $\mathrm{X}$ & & {$[\mathrm{X}]$} & & & {$[\mathrm{X}]$} & & & \\
\hline Greith, Karl & Ave maris stella (E-dur) & $\mathrm{X}$ & & {$[\mathrm{X}]$} & & & {$[\mathrm{X}]$} & & & \\
\hline Hahn, B[ernhard] & Diffusa est gratia (E-dur) & $\mathrm{X}$ & & {$[\mathrm{X}]$} & & & {$[\mathrm{X}]$} & & & \\
\hline Haydn, Jos[eph] & $\begin{array}{l}\text { Ofertorij za tretjo božično } \\
\text { mašo }\end{array}$ & & & {$[\mathrm{X}]$} & & & {$[\mathrm{X}]$} & $\mathrm{X}$ & & \\
\hline $\begin{array}{l}\text { Hoffmann, } \\
\text { L[eopold] }\end{array}$ & Bonum est confiteri & $\mathrm{X}$ & & - & & & - & & & \\
\hline \begin{tabular}{|l|} 
Horack, W[enzel] \\
E[manuel]
\end{tabular} & Bone deus & $\mathrm{X}$ & & {$[\mathrm{X}]$} & & & {$[\mathrm{X}]$} & & & \\
\hline \begin{tabular}{|l|} 
Horack, W[enzel] \\
E[manuel $]$ \\
\end{tabular} & Concupivit rex & $\mathrm{x}$ & & {$[\mathrm{X}]$} & & & {$[\mathrm{X}]$} & & & \\
\hline \begin{tabular}{|l|} 
Horack, W[enzel] \\
E[manuel]
\end{tabular} & Vias tuas (prir. za moški zbor) & $\mathrm{X}$ & & {$[\mathrm{X}]$} & & & {$[\mathrm{X}]$} & & & \\
\hline Janez IV. Portugalski & Crux fidelis & $\mathrm{X}$ & $\mathrm{X}$ & & $\mathrm{X}$ & $\mathrm{X}$ & - & & & \\
\hline Jelen, A[lois] & $\begin{array}{l}\text { Benedicta et venerabilis (pri- } \\
\text { rejena) }\end{array}$ & $\mathrm{X}$ & & {$[\mathrm{X}]$} & & & - & & & \\
\hline $\begin{array}{l}\text { Kloss, Jos[ef] } \\
\text { Ferd[inand] } \\
\end{array}$ & Regina coeli & $\mathrm{x}$ & & - & & & - & & & \\
\hline Knahl[, Jan Krtitel] & Mane nobiscum & $\mathrm{X}$ & & & $\mathrm{X}$ & & - & & & \\
\hline $\begin{array}{l}\text { Koral (s spremljavo } \\
\text { [Josepha] Hanischa) }\end{array}$ & & $\mathrm{X}$ & $\mathrm{X}$ & {$[\mathrm{X}]$} & & & & & & \\
\hline Kothe[, Bernhard] & Iz zbirke katol. moških zborov & $\mathrm{X}$ & & - & & & - & & & \\
\hline Krejči, Joh[ann] & $\begin{array}{l}\text { Benedicta et venerabilis, op. } 10 \\
\text { (z instrumenti) }\end{array}$ & $\mathrm{X}$ & & {$[\mathrm{X}]$} & & & - & & & \\
\hline Kunz, A. & O salutaris hostia (iz CG) & & & & & $\mathrm{X}$ & - & & & \\
\hline Leitner[, C. A.] & Regina coeli (z instrumenti) & & $\mathrm{X}$ & {$[\mathrm{X}]$} & $\mathrm{X}$ & $\mathrm{X}$ & - & & & \\
\hline Lickl, C[arl] G[eorg] & Bone Deus & $\mathrm{X}$ & & - & & & - & & & \\
\hline
\end{tabular}


A. Nagode: Poskus rekonstrukcije latinskih cerkvenih skladb na koru ljubljanske stolnice ...

\begin{tabular}{|c|c|c|c|c|c|c|c|c|c|c|}
\hline & & 1876 & \begin{tabular}{|c|} 
VEL. \\
NOČ \\
1880 \\
\end{tabular} & \begin{tabular}{l|} 
ZAČ. \\
1882
\end{tabular} & $\begin{array}{l}\text { VEL. } \\
\text { NOČ } \\
1882 \\
\end{array}$ & \begin{tabular}{|l} 
VEL. \\
NOČ \\
1883 \\
\end{tabular} & 1886 & $\begin{array}{c}\text { BOŽIČ } \\
1887\end{array}$ & 1891 & 1901 \\
\hline Lickl, C[arl] G[eorg] & $\begin{array}{l}\text { Ave Maria op. } 70 \text { ( } 2 \text { gl. z } \\
\text { orglami) }\end{array}$ & $\mathrm{X}$ & & - & & & - & & & \\
\hline Liszt, $\operatorname{Fr}[\operatorname{anz}]$ & Ave Maria (B-dur) & $\mathrm{X}$ & & {$[\mathrm{X}]$} & & & - & & & \\
\hline Liszt, $\operatorname{Fr}[\operatorname{anz}]$ & Ave Maria (D-dur) & $\mathrm{X}$ & & {$[\mathrm{X}]$} & & & - & & & \\
\hline Lotti, Antonio & Vere languores (3 gl.) & $\mathrm{X}$ & & & & & {$[\mathrm{X}]$} & & & \\
\hline $\begin{array}{l}\text { Martini[, Giovanni } \\
\text { Battista] }\end{array}$ & Tristis est anima & $\mathrm{X}$ & $\mathrm{X}$ & {$[\mathrm{X}]$} & & $\mathrm{X}$ & {$[\mathrm{X}]$} & & & \\
\hline $\begin{array}{l}\text { Mechura, [Leopold] } \\
\text { Eug[en] }\end{array}$ & Ave Maria (moški zbor) & $\mathrm{X}$ & & - & & & - & & & \\
\hline $\begin{array}{l}\text { Mendelssohn- } \\
\text { B[artholdy, Felix] }\end{array}$ & Ave Maria ( 8 gl. $\mathrm{z}$ orglami) & $\mathrm{X}$ & & - & & & - & & & \\
\hline Menegali & Parce Domine & $\mathrm{X}$ & & {$[\mathrm{X}]$} & & & - & & & \\
\hline Menegali & Jesu Salvator (3 gl.) & $\mathrm{X}$ & & {$[\mathrm{X}]$} & & & - & & & \\
\hline $\begin{array}{l}\text { Mettenleiter, } \\
\text { J[ohann] G[eorg] }\end{array}$ & Gradualia pro dom. Quadrag. & $\mathrm{X}$ & & {$[\mathrm{X}]$} & & & - & & & \\
\hline $\begin{array}{l}\text { Meyerbeer[, Gia- } \\
\text { como] }\end{array}$ & Pater noster & $\mathrm{X}$ & $\mathrm{X}$ & - & & & - & & & \\
\hline Mossmeier, A. & Caligaverunt & $\mathrm{X}$ & $\mathrm{X}$ & - & & & - & & & \\
\hline $\begin{array}{l}\text { Mozart, W[olfgang] } \\
\mathrm{A}[\text { madeus }]\end{array}$ & Ave verum & $\mathrm{X}$ & & {$[\mathrm{X}]$} & & $\mathrm{X}$ & {$[\mathrm{X}]$} & & & \\
\hline $\begin{array}{l}\text { Müller, J[ohann] } \\
\text { B[aptist] }\end{array}$ & O Deus, ego amo te & $\mathrm{X}$ & & - & & & - & & & \\
\hline Musiol, Rob[ert] & Confitemini & $\mathrm{X}$ & & - & & & - & & & \\
\hline Nedved, A[nton] & Bone Deus (solo z orglami) & $\mathrm{X}$ & & {$[\mathrm{X}]$} & & & {$[\mathrm{X}]$} & & & \\
\hline Nedved, A[nton] & Benedic anima (solo z orglami) & $\mathrm{X}$ & & {$[\mathrm{X}]$} & & & {$[\mathrm{X}]$} & & & \\
\hline Nehr, K. & O salutaris hostia (moški zbor) & & & & $\mathrm{X}$ & & - & & & \\
\hline $\begin{array}{l}\text { Oberhoffer, } \\
\text { H[einrich] }\end{array}$ & $\begin{array}{l}\text { Ave Maria op. } 34 \text { (solo z } \\
\text { orglami) }\end{array}$ & $\mathrm{X}$ & & {$[\mathrm{X}]$} & & & {$[\mathrm{X}]$} & & & \\
\hline Olivieri, G[iuseppe] & Veni s. Spiritus & $\mathrm{X}$ & & {$[\mathrm{X}]$} & & & - & & & \\
\hline Palestrina & Stabat Mater (8 gl.) & & & {$[\mathrm{X}]$} & $\mathrm{X}$ & & {$[\mathrm{X}]$} & & & \\
\hline $\begin{array}{l}\text { Pitoni, G[iuseppe] } \\
\text { O[ttavio] }\end{array}$ & Laudate Dominum & $\mathrm{X}$ & & {$[\mathrm{X}]$} & & & {$[\mathrm{X}]$} & & & \\
\hline Preyer, G[ottfried] & $\begin{array}{l}\text { Gradual za praznik brezmade- } \\
\text { žnega spočetja }\end{array}$ & & & & & & - & $\mathrm{X}$ & & \\
\hline Preyer, Got[tfried] & Benedicta es, op. 74 & $\mathrm{X}$ & & {$[\mathrm{X}]$} & & & - & & & \\
\hline Preyer, Got[tfried] & Beata es & $\mathrm{X}$ & & {$[\mathrm{X}]$} & & & - & & & \\
\hline Preyer, Got[tfried] & Ave Maria & $\mathrm{X}$ & & {$[\mathrm{X}]$} & & & - & & & \\
\hline Rampis, $\mathrm{P}$. & Alma redemptoris & $\mathrm{X}$ & & {$[\mathrm{X}]$} & & & {$[\mathrm{X}]$} & & & \\
\hline Rieder, $\mathrm{A}[\mathrm{mbros}]$ & 4 ofertoriji & $\mathrm{X}$ & & - & & & - & & & \\
\hline Rind, Ch. H. & Offero tibi (prirejeno) & $\mathrm{X}$ & & - & & & - & & & \\
\hline $\begin{array}{l}\text { Scarlatti, } \\
\text { Aless[andro] }\end{array}$ & Exultate Deo & $\mathrm{X}$ & & {$[\mathrm{X}]$} & & & - & & & \\
\hline $\begin{array}{l}\text { Schaller, } \\
\text { Ferd[inand] }\end{array}$ & 14 motetov [gradualov, op. 55] & $\mathrm{X}$ & & {$[\mathrm{X}]$} & & & {$[\mathrm{X}]$} & & & \\
\hline
\end{tabular}




\begin{tabular}{|c|c|c|c|c|c|c|c|c|c|c|}
\hline & & 1876 & \begin{tabular}{|l} 
VEL. \\
NOČ \\
1880
\end{tabular} & $\begin{array}{l}\text { ZAČ. } \\
1882\end{array}$ & \begin{tabular}{|l} 
VEL. \\
NOČ \\
1882
\end{tabular} & \begin{tabular}{|l|} 
VEL. \\
NOČ \\
1883
\end{tabular} & 1886 & $\begin{array}{c}\text { BOŽIČ } \\
1887\end{array}$ & 1891 & 1901 \\
\hline Schöpf, Fr[anz] & Deus in auribus & $\mathrm{X}$ & & {$[\mathrm{X}]$} & & & {$[\mathrm{X}]$} & & & \\
\hline Schöpf, Fr[anz] & Exultabo te & $\mathrm{X}$ & & {$[\mathrm{X}]$} & & & {$[\mathrm{X}]$} & & & \\
\hline Schöpf, Fr[anz] & Regina coeli op. 21 & $\mathrm{X}$ & & {$[\mathrm{X}]$} & & & {$[\mathrm{X}]$} & & & \\
\hline Schöpf, Fr[anz] & Salve regina & $\mathrm{X}$ & & {$[\mathrm{X}]$} & & & {$[\mathrm{X}]$} & & & \\
\hline Seiler, Jos[seph] & Laudate Dominum (odlomki) & $\mathrm{X}$ & & - & & & - & & & \\
\hline \begin{tabular}{|l|} 
Skuhersky, \\
F[rantišek] \\
Z[denek] \\
\end{tabular} & Gradual za tretjo božično mašo & & & & & & - & $\mathrm{X}$ & & \\
\hline $\begin{array}{l}\text { Skuhersky[, Franti- } \\
\text { šek Zdenek] }\end{array}$ & Gradual za veliki ponedeljek & & & & & $\mathrm{X}$ & - & & & \\
\hline Spohr, L[ouis] & Exaudi me (prirejeno) & $\mathrm{X}$ & & & & $\mathrm{X}$ & - & & & \\
\hline Stehle, G. E. & $\begin{array}{l}\text { Ofertorij za velikonočni pone- } \\
\text { deljek [Angelus Domini] }\end{array}$ & $\mathrm{X}$ & $\mathrm{x}$ & {$[\mathrm{X}]$} & $\mathrm{X}$ & $\mathrm{X}$ & {$[\mathrm{X}]$} & & & \\
\hline Stern, J[ohann] & Respice Domine (prirejeno) & $\mathrm{X}$ & & - & & & - & & & \\
\hline \begin{tabular}{|l|} 
Sturm, J[ohann] \\
B[aptist] \\
\end{tabular} & Adjuva nos & $\mathrm{X}$ & & - & & & - & & & \\
\hline Turini, G[regorio] & Hodie Christus natus est & $\mathrm{X}$ & & - & & & - & & & \\
\hline Uerlichs & $\begin{array}{l}\text { Exaudi me Domine (moški } \\
\text { zbor) }\end{array}$ & $\mathrm{X}$ & & - & & & - & & & \\
\hline \begin{tabular}{|l|} 
Viadana, L[odovico \\
Grossi da] \\
\end{tabular} & $\begin{array}{l}\text { Exaudi me Domine (1 glas in } \\
\text { orgle) }\end{array}$ & $\mathrm{X}$ & & {$[\mathrm{X}]$} & & & {$[\mathrm{X}]$} & & & \\
\hline \begin{tabular}{|l|} 
Vittoria [=Victoria, \\
Tomas Louis de] \\
\end{tabular} & Improperia [Popule meus] & $\mathrm{X}$ & $\mathrm{X}$ & {$[\mathrm{X}]$} & $\mathrm{X}$ & $\mathrm{X}$ & {$[\mathrm{X}]$} & & & \\
\hline Vogelmann & Ave maris stella (dvozborsko) & $\mathrm{X}$ & & - & & & - & & & \\
\hline Wesselack, J. G. & Confitebuntur & $\mathrm{X}$ & & {$[\mathrm{X}]$} & & & - & & & \\
\hline Wesselack, J. G. & Inveni David & $\mathrm{X}$ & & {$[\mathrm{X}]$} & & & - & & & \\
\hline Wesselack, J. G. & Justus ut palma & $\mathrm{X}$ & & {$[\mathrm{X}]$} & & & - & & & \\
\hline Wesselack, J. G. & O Deus, ego amo te & $\mathrm{X}$ & & {$[\mathrm{X}]$} & & & - & & & \\
\hline Witt, Fr[anz X.] & Alleluia. Confitemini & $\mathrm{X}$ & & {$[\mathrm{X}]$} & & & {$[\mathrm{X}]$} & & & \\
\hline Witt, $\operatorname{Fr}[\operatorname{anz} \mathrm{X}]$. & Alleluia. De quacunque & $\mathrm{X}$ & & {$[\mathrm{X}]$} & & & {$[\mathrm{X}]$} & & & \\
\hline Witt, $\operatorname{Fr}[\operatorname{anz} \mathrm{X}]$. & Angelis suis & $\mathrm{X}$ & & {$[\mathrm{X}]$} & & & {$[\mathrm{X}]$} & & & \\
\hline Witt, Fr[anz X.] & Aurora coelum purpurat & $\mathrm{X}$ & $\mathrm{X}$ & {$[\mathrm{X}]$} & $\mathrm{X}$ & $\mathrm{X}$ & {$[\mathrm{X}]$} & & & \\
\hline Witt, Fr[anz X.] & Calix bened. & $\mathrm{X}$ & & {$[\mathrm{X}]$} & & & {$[\mathrm{X}]$} & & & \\
\hline Witt, Fr[anz X.] & Christus factus est & $\mathrm{X}$ & & {$[\mathrm{X}]$} & & & {$[\mathrm{X}]$} & & & \\
\hline Witt[, Franz X.] & Gradual za veliki četrtek & & $\mathrm{X}$ & {$[\mathrm{X}]$} & $\mathrm{X}$ & $\mathrm{X}$ & {$[\mathrm{X}]$} & & & \\
\hline Witt[, Franz X.] & Gradual za veliko soboto & & $\mathrm{X}$ & {$[\mathrm{X}]$} & $\mathrm{X}$ & $\mathrm{X}$ & {$[\mathrm{X}]$} & & & \\
\hline Witt[, Franz X.] & Gradual za cvetno nedeljo & & & & $\mathrm{X}$ & $\mathrm{X}$ & {$[\mathrm{X}]$} & & & \\
\hline Witt[, Franz X.] & Improperium expectavit me & & $\mathrm{X}$ & {$[\mathrm{X}]$} & $\mathrm{X}$ & & {$[\mathrm{X}]$} & & & \\
\hline Witt[, Franz X.] & Inveni David & & & & & & & $\mathrm{X}$ & & \\
\hline Witt, $\operatorname{Fr}[\operatorname{anz} \mathrm{X}]$. & In omnem terram & $\mathrm{X}$ & & {$[\mathrm{X}]$} & & & {$[\mathrm{X}]$} & & & \\
\hline Witt[, Franz X.] & O salutaris hostia (4 gl.) & $\mathrm{X}$ & $\mathrm{X}$ & {$[\mathrm{X}]$} & & & {$[\mathrm{X}]$} & $\mathrm{X}$ & & \\
\hline Witt[, Franz X.] & $\begin{array}{l}\text { Ofertorij za praznik brezmade- } \\
\text { žnega spočetja }\end{array}$ & & & & & & & $\mathrm{X}$ & & \\
\hline
\end{tabular}


A. Nagode: Poskus rekonstrukcije latinskih cerkvenih skladb na koru ljubljanske stolnice ...

\begin{tabular}{|c|c|c|c|c|c|c|c|c|c|c|}
\hline & & 1876 & \begin{tabular}{|l} 
VEL. \\
NOČ \\
1880
\end{tabular} & $\begin{array}{l}\text { ZAČ. } \\
1882\end{array}$ & \begin{tabular}{|l} 
VEL. \\
NOČ \\
1882
\end{tabular} & \begin{tabular}{|l|} 
VEL. \\
NOČ \\
1883
\end{tabular} & 1886 & $\begin{array}{c}\text { BOŽIČ } \\
1887\end{array}$ & 1891 & 1901 \\
\hline Witt, Fr[anz X.] & Offert. pro dom. Adv. & $\mathrm{X}$ & & {$[\mathrm{X}]$} & & & {$[\mathrm{X}]$} & $\mathrm{X}$ & & \\
\hline Witt, Fr[anz X.] & Offert. pro. dom. Quadr. & $\mathrm{X}$ & & {$[\mathrm{X}]$} & & & {$[\mathrm{X}]$} & & & \\
\hline Witt, Fr[anz X.] & Perfice & $\mathrm{X}$ & & {$[\mathrm{X}]$} & & & {$[\mathrm{X}]$} & & & \\
\hline Witt, Fr[anz X.] & Rorate & $\mathrm{X}$ & & {$[\mathrm{X}]$} & & & {$[\mathrm{X}]$} & & & \\
\hline Witt, $\operatorname{Fr}[\operatorname{anz} X]$. & Tenuisti & $\mathrm{X}$ & & {$[\mathrm{X}]$} & & & {$[\mathrm{X}]$} & & & \\
\hline Witt, Fr[anz X.] & Veritas mea & $\mathrm{X}$ & & {$[\mathrm{X}]$} & & & {$[\mathrm{X}]$} & & & \\
\hline Witt, Fr[anz X.] & Veni creator (A-dur) & $\mathrm{X}$ & & {$[\mathrm{X}]$} & & & {$[\mathrm{X}]$} & & & \\
\hline Witt[, Franz X.] & Velum templi scissum est & & $\mathrm{X}$ & {$[\mathrm{X}]$} & $\mathrm{X}$ & & {$[\mathrm{X}]$} & & & \\
\hline \multirow{3}{*}{$\begin{array}{l}\text { Zangl, [Joseph] } \\
\text { G[regor] }\end{array}$} & Haec dies (moški zbor) & $\mathrm{X}$ & $\mathrm{X}$ & {$[\mathrm{X}]$} & $\mathrm{X}$ & $\mathrm{X}$ & {$[\mathrm{X}]$} & & & \\
\hline & $\begin{array}{l}\text { Moteti iz zbirke Lauda Sion (ur. } \\
\text { Emil Nickl) }\end{array}$ & & & & & & & & & $\mathrm{X}$ \\
\hline & $\begin{array}{l}\begin{array}{l}\text { Število neidentificiranih } \\
\text { motetov }^{* *}\end{array} \\
\end{array}$ & & & & & & & & & 200 \\
\hline \multicolumn{11}{|l|}{ Te Deumi } \\
\hline $\begin{array}{l}\text { Förster [=Foerster], } \\
\text { A[nton] }\end{array}$ & $\begin{array}{l}\text { Te Deum v C-duru (z instru- } \\
\text { menti) }\end{array}$ & $\mathrm{X}$ & & {$[\mathrm{X}]$} & & & {$[\mathrm{X}]$} & & & {$[\mathrm{X}]$} \\
\hline $\begin{array}{l}\text { Förster [=Foerster], } \\
\mathrm{A}[\text { nton] }\end{array}$ & Te Deum v D-duru & $\mathrm{X}$ & & {$[\mathrm{X}]$} & & & {$[\mathrm{X}]$} & & & {$[\mathrm{X}]$} \\
\hline $\begin{array}{l}\text { Förster [=Foerster], } \\
\text { A[nton] }\end{array}$ & Te Deum v G-duru & $\mathrm{X}$ & & {$[\mathrm{X}]$} & & $\mathrm{X}$ & {$[\mathrm{X}]$} & & & {$[\mathrm{X}]$} \\
\hline $\begin{array}{l}\text { Förster [=Foerster], } \\
\text { A[nton] }\end{array}$ & $\begin{array}{l}\text { Te Deum v h-molu (z instru- } \\
\text { menti) }\end{array}$ & $\mathrm{X}$ & & {$[\mathrm{X}]$} & & & {$[\mathrm{X}]$} & & & {$[\mathrm{X}]$} \\
\hline Gruber[, Josef] & $\begin{array}{l}\text { [Te Deum op. } 38 \text { ali Te Deum } \\
\text { in C, op. 125] }\end{array}$ & & & & & & & & & {$[\mathrm{X}]$} \\
\hline Kempter, Karl & $\begin{array}{l}\text { Te Deum v C-duru (na koralne } \\
\text { melodije) }\end{array}$ & $\mathrm{X}$ & $\mathrm{X}$ & {$[\mathrm{X}]$} & $\mathrm{X}$ & & {$[\mathrm{X}]$} & & & {$[\mathrm{X}]$} \\
\hline Molitor[, J. B.] & [Te Deum v C, op. 22] & & & & & & {$[\mathrm{X}]$} & & & {$[\mathrm{X}]$} \\
\hline \begin{tabular}{|l|} 
Röder, G[eorg] \\
V[alentin] \\
\end{tabular} & $\begin{array}{l}\text { Te Deum v D-duru (z instru- } \\
\text { menti, skrajšan) }\end{array}$ & $\mathrm{X}$ & & - & & & - & & & - \\
\hline \multirow[t]{2}{*}{ Witt[, Franz X.] } & & & & & & & {$[\mathrm{X}]$} & & & {$[\mathrm{X}]$} \\
\hline & $\begin{array}{l}\text { Število neidentificiranih } \mathrm{Te} \\
\text { Deumov }^{* \star}\end{array}$ & & & 2 & & & 3 & & 10 & 5 \\
\hline \multicolumn{11}{|l|}{ Tantum ergo } \\
\hline \begin{tabular}{|l|} 
Ett, [Joseph] \\
Kasp[ar]
\end{tabular} & Tantum ergo (1) & $\mathrm{X}$ & & {$[\mathrm{X}]$} & & & {$[\mathrm{X}]$} & & & \\
\hline $\begin{array}{l}\text { Förster [=Foerster], } \\
\mathrm{A}[\text { nton] }\end{array}$ & Tantum ergo (6) & $\mathrm{X}$ & & {$[\mathrm{X}]$} & & & {$[\mathrm{X}]$} & & & \\
\hline Hanisch, J[oseph] & Tantum ergo (1) & $\mathrm{X}$ & $\mathrm{X}$ & & & & {$[\mathrm{X}]$} & & & \\
\hline Kempter, K[arl] & Tantum ergo (7) & $\mathrm{X}$ & & {$[\mathrm{X}]$} & & & {$[\mathrm{X}]$} & & & \\
\hline Nedved, A[nton] & Tantum ergo (3) & $\mathrm{X}$ & & {$[\mathrm{X}]$} & & & {$[\mathrm{X}]$} & & & \\
\hline $\begin{array}{l}\text { Pitoni, G[iuseppe] } \\
\text { O[ttavio] }\end{array}$ & Tantum ergo (1) & $\mathrm{X}$ & & {$[\mathrm{X}]$} & & & {$[\mathrm{X}]$} & & & \\
\hline
\end{tabular}




\begin{tabular}{|c|c|c|c|c|c|c|c|c|c|c|}
\hline & & 1876 & \begin{tabular}{l|} 
VEL. \\
NOČ \\
1880 \\
\end{tabular} & \begin{tabular}{|l|} 
ZAČ. \\
1882 \\
\end{tabular} & \begin{tabular}{|c|} 
VEL. \\
NOČ \\
1882 \\
\end{tabular} & \begin{tabular}{|l|} 
VEL. \\
NOČ \\
1883 \\
\end{tabular} & 1886 & $\begin{array}{c}\text { BOŽIČ } \\
1887\end{array}$ & 1891 & 1901 \\
\hline $\begin{array}{l}\text { Schmid, Fr[anz] } \\
\text { X[aver] }\end{array}$ & Tantum ergo (12) & $\mathrm{X}$ & & - & & & - & & & \\
\hline Seiler, Jos[eph] & Tantum ergo (1) & $\mathrm{X}$ & & - & & & - & & & \\
\hline Traumihler[, Ignaz] & Tantum ergo (1) & $\mathrm{X}$ & & - & & & - & & & \\
\hline \begin{tabular}{|l|} 
Vittoria [=Victoria, \\
Tomas Louis de] \\
\end{tabular} & Tantum ergo (1) & $\mathrm{X}$ & & {$[\mathrm{X}]$} & & $\mathrm{X}$ & {$[\mathrm{X}]$} & & & \\
\hline Vollmar, H. & Tantum ergo $(1$, prirejen $)$ & $\mathrm{X}$ & & - & & & - & & & \\
\hline Waldeck, J. E. & Tantum ergo (1) & $\mathrm{X}$ & & & $\mathrm{X}$ & & - & & & \\
\hline Witt, Fr[anz X.] & Tantum ergo (3) & $\mathrm{X}$ & & {$[\mathrm{X}]$} & & & {$[\mathrm{X}]$} & & & \\
\hline \begin{tabular}{|l|} 
Zangl, J[oseph] \\
G[regor] \\
\end{tabular} & 4 Tantum ergo, op. 69 & $\mathrm{X}$ & & {$[\mathrm{X}]$} & & & {$[\mathrm{X}]$} & & & \\
\hline \multirow[t]{2}{*}{ Koral } & Tantum ergo (2) z orglami & $\mathrm{X}$ & & {$[\mathrm{X}]$} & & & & & & \\
\hline & $\begin{array}{l}\text { Število neidentificiranih } \\
\text { Tantum ergo }\end{array}$ & & & 25 & & & 40 & & & 90 \\
\hline \multicolumn{11}{|l|}{$\begin{array}{l}\text { Skladatelji, zasto- } \\
\text { pani z neidentifici- } \\
\text { ranimi skladbami }\end{array}$} \\
\hline Aichinger[, Gregor] & & & & & & & $\mathrm{X}$ & & & \\
\hline Fajgelj[, Danilo] & & & & $\mathrm{X}$ & & & $\mathrm{X}$ & & & \\
\hline Kornmüller[, Utto] & & & & & & & $\mathrm{X}$ & & & \\
\hline Lavtižar[, Josip] & & & & & & & $\mathrm{X}$ & & & \\
\hline Sattner[, p. Hugolin] & & & & & & & $\mathrm{X}$ & & & \\
\hline $\begin{array}{l}\text { Skuhersky[, Franti- } \\
\text { šek Zdenek] }\end{array}$ & & & & $\mathrm{X}$ & & & - & & & \\
\hline
\end{tabular}

* Skladbe so bile izvedene prirejene.

** Vir navaja pogosto le skupno število skladb posamezne zvrsti in njihove avtorje. 


\title{
THE LATIN CHURCH MUSIC REPERTOIRE \\ IN THE CATHEDRAL OF LJUBLJANA DURING THE TIME OF \\ ANTON FOERSTER (1868-1908))
}

\begin{abstract}
Summary
The choir of the Ljubljana cathedral was the most important musical institution in Slovenia, devoted to cultivation of church music from the $15^{\text {th }}$ century onwards. Its activity had considerable impact on the repertoire of the smaller churches. This influence was even stronger for its formal status as the principal church of the Ljubljana diocese. As Ljubljana was asserting its role more and more as the cultural centre of Slovenian ethnic territory in the $19^{\text {th }}$ century, this influence spread to the neighbouring dioceses of Maribor/Lavant, Trst (Triest) and Gorica (Gorizia). Therefore, observation of its activity has great significance for understanding the development of the Cecilian movement in Slovenia in the second half of the $19^{\text {th }}$ century.

The main difficulty in reconstructing the repertoire of the Ljubljana cathedral choir lies in its scarce and deficient sources. The repertoire of Anton Foerster's predecessors can be only partially reconstructed with data from the inventory of the cathedral's musical archive, drawn up in 1865. He himself ignored the guidelines of the Cecilian authors and avoided taking notes of the performed compositions. Our knowledge of his performance of activities is thus based only on his sporadic reports, which were published in the magazines Musica sacra (German, 1876) and Cerkveni glasbenik (Slovene, 1880, 1882, 1883, 1886, $1887,1891,1901)$. Some of those accounts are perfunctory, so the data are incomplete and partly unreliable. The list of performed musical pieces presented in Table 2 is thus supplemented with data which are result of the author's research (some musical pieces have been identified with the help of a 1944 musical archive inventory list) and qualified guess (all these supplements are in square brackets).

The whole span of Foerster's activity in the Ljubljana cathedral choir can be - according to developments in its repertoire - divided into two periods. In the first (1868-1876), he shaped the relatively large and entirely new (he used only 7 out of nearly 300 compositions already present in cathedral's musical archive) repertoire of Latin church music. The chosen works can be divided into three groups, represented almost evenly: Early $19^{\text {th }}$ century German, Austrian and Czech masters; German and Bohemian composers, inclined to the aims of the Cecilian movement; and $16^{\text {th }}$ and $17^{\text {th }}$ century masters of vocal polyphony. The second period (1876-1908) is characterized by a noticeable invariability of the repertoire. Several older $19^{\text {th }}$ century compositions were replaced with works by younger Cecilian authors, linked with the so-called "Munich-Austrian group".
\end{abstract}

